\title{
Global baselines and benchmarks for fish biomass: comparing remote reefs and fisheries closures
}

\author{
Tim R. McClanahan ${ }^{1, *}$, Robert E. Schroeder ${ }^{2}$, Alan M. Friedlander ${ }^{3,4}$, Laurent Vigliola ${ }^{5}$, \\ Laurent Wantiez ${ }^{6}$, Jennifer E. Caselle ${ }^{7}$, Nicholas A. J. Graham ${ }^{8}$, Shaun Wilson ${ }^{9,10}$, \\ Graham J. Edgar ${ }^{11}$, Rick D. Stuart-Smith ${ }^{11}$, Remy M. Oddenyo ${ }^{12}$, J. E. Cinner ${ }^{13}$ \\ ${ }^{1}$ Wildlife Conservation Society, Marine Programs, Bronx, NY 10460, USA \\ ${ }^{2}$ National Oceanic and Atmospheric Administration Fisheries, Honolulu, HI 96818, USA \\ ${ }^{3}$ Pristine Seas, National Geographic Society, Washington, DC 20036, USA \\ ${ }^{4}$ Fisheries Ecology Research Lab, University of Hawaii, Honolulu, HI 96822, USA \\ ${ }^{5}$ Institut de Recherche pour le Développement (IRD), UMR ENTROPIE, Laboratoire Excellence LABEX Corail, 98851 Noumea, \\ New Caledonia, France \\ ${ }^{6}$ Institut De Sciences Exactes Et Appliquées (ISEA), EA7484, University of New Caledonia, 98851 Noumea, New Caledonia, France \\ ${ }^{7}$ Marine Science Institute, University of California Santa Barbara, Santa Barbara, CA 93106, USA \\ ${ }^{8}$ Lancaster Environment Centre, Lancaster University, Lancaster LA1 4YQ, UK \\ ${ }^{9}$ Department of Biodiversity Conservation and Attractions, Kensington, WA 6151, Australia \\ ${ }^{10}$ Oceans Institute, University of Western Australia, Crawley, WA 6009, Australia \\ ${ }^{11}$ Institute for Marine and Antarctic Studies, University of Tasmania, Hobart, TAS 7001, Australia \\ ${ }^{12}$ Wildlife Conservation Society, Coral Reef Conservation Program, Mombasa 80107, Kenya \\ ${ }^{13}$ Australian Research Council, James Cook University, Townsville, QLD 4811, Australia
}

\begin{abstract}
Baselines and benchmarks (B\&Bs) are needed to evaluate the ecological status and fisheries potential of coral reefs. B\&Bs may depend on habitat features and energetic limitations that constrain biomass within the natural variability of the environment and fish behaviors. To evaluate if broad B\&Bs exist, we compiled data on the biomass of fishes in 1000 reefs with no recent history of fishing in 19 ecoregions. These reefs spanned the full longitude and latitude of Indian and Pacific Ocean reefs and included older high-compliance fisheries closures ( $>15 \mathrm{yr}$ closure) and remote reef areas ( $>9 \mathrm{~h}$ travel time from fisheries markets). There was no significant change in biomass over the 15 to $48 \mathrm{yr}$ closure period but closures had only $\sim 40 \%$ of the biomass (740 kg ha ${ }^{-1}$, lower confidence interval $[\mathrm{LCI}]=660 \mathrm{~kg} \mathrm{ha}^{-1}$, upper confidence interval [UCI] $=$ $\left.810 \mathrm{~kg} \mathrm{ha}^{-1}, \mathrm{n}=157\right)$ of remote tropical reefs $\left(1870[1730,2000] \mathrm{kg} \mathrm{ha}^{-1}, \mathrm{n}=503\right)$. Remote subtropical reefs had lower biomass $\left(950[860,1040] \mathrm{kg} \mathrm{ha}^{-1}, \mathrm{n}=329\right)$ than tropical reefs. Closures and remote reef fish biomass responded differently to environmental variables of coral cover, net primary productivity, and light, indicating that remote reefs are more limited by productivity and habitat than closures. Closures in fished seascapes are unlikely to achieve the biomass and community composition of remote reefs, which suggests fisheries benchmarks will differ substantially from wilderness baselines. A fishery benchmark $\left(B_{0}\right)$ of $\sim 1000 \mathrm{~kg} \mathrm{ha}^{-1}$ adjusted for geography is suggested for fisheries purposes. For ecological purposes, a wilderness baseline of $\sim 1900 \mathrm{~kg} \mathrm{ha}^{-1}$ is appropriate for including large and mobile species not well protected by closures.
\end{abstract}

KEY WORDS: Baselines · Coral reef fish · Fisheries and ecological indicators · Pristine or virgin biomass $\cdot$ Sustainability 


\section{INTRODUCTION}

Measurable baselines and benchmarks (B\&Bs) are critical for evaluating and comparing the status of natural ecosystems (Rice \& Rochet 2005, Levin et al. 2009). Fisheries are particularly difficult to assess and manage without knowing carrying capacity $(K)$, unfished biomass $\left(B_{0}\right)$, and rates of fishing mortality $(M)$ and recovery ( $r$ ) (Worm et al. 2009). Numerous factors at many scales are expected to influence B\&Bs and potentially preclude their utility except under very limited circumstances. Given the pervasiveness of human impacts, it is increasingly difficult to find natural B\&Bs, even in the seemingly vast ocean (Mora et al. 2011, Halpern et al. 2012). For example, unsustainable fishing, climate change, pollution, warm temperature anomalies, and an increasing frequency and intensity of storms are threatening marine ecosystems (Webster et al. 2005, Cinner et al. 2016, Hughes et al. 2017). Even remote reef areas experience human impacts of fishing and the effects of climate disturbances, making large-scale natural baselines increasingly rare (Graham \& McClanahan 2013, Bruno \& Valdivia 2016). There are, however, old high-compliance fisheries closures and remote reef areas that may have no recent historical fishing mortality and therefore be useful for estimating B\&Bs (Sandin et al. 2008, McClanahan \& Graham 2015, D'agata et al. 2016). In principle, good B\&Bs should display properties of hard natural resource limitations set by broad-scale energy inputs, nutrients, and habitat limitations.

Coral reef fisheries have a high diversity of target taxa, which make stock-specific evaluations of fisheries sustainability difficult (Worm et al. 2009, MacNeil et al. 2015). While the practical need is great, only wealthy countries may be able to develop the taxa-specific management needed to evaluate diverse and spatially heterogeneous coral reef fisheries (Ault et al. 2005, Nadon et al. 2015). An alternative approach is to establish multispecies B\&Bs that include all species combined, or the subset of species targeted by fishers (McClanahan 2019). However, high variability and complex interactions among species and variable environmental factors could undermine efforts to practically bound estimates of biomass. For example, a large survey of reef fish in fisheries closures found that many large top-level predators were virtually absent or too uncommon to sample accurately when closures were located close to fisheries markets (Cinner et al. 2018). Yet other studies have shown that the combination of protection from fishing and isolation from human influ- ences can support high biomass and large roaming predators such as sharks (Stevenson et al. 2007, McCauley et al. 2012, Edgar et al. 2014, Bradley et al. 2017, Juhel et al. 2018).

Numerous medium-scale ecological field studies (i.e. $<0.1$ ha) have found that fish density and biomass are influenced by a number of factors such as the cover of hard coral, reef complexity, habitat, and productivity of adjacent ecosystems (Wilson et al. 2008, Graham \& Nash 2013, Williams et al. 2015, Cinner et al. 2016, Heenan et al. 2016, Darling et al. 2017, Valdivia et al. 2017). Furthermore, there is the potential for the composition of fish communities to influence production and biomass, as determined by their life histories, food web configurations, and community diversity (Mora et al. 2014, Duffy et al. 2016). Despite these findings, there are energetic limits to ecological production and its transformation into animal biomass (Odum 1988). Estimates of benthic primary production have generally been constrained within modest ranges, suggesting a potential limiting factor for the dependent fish (McClanahan 1992, Atkinson et al. 2011, Falter et al. 2013). Consequently, limits to solar intensity and primary production may underlie and constrain animal biomass. Production may be influenced by regionally specific environmental factors, but latitude and, to a lesser extent, longitude influence solar intensity, its seasonal variability, and the kinetic energy of waves and currents (Kleypas et al. 1999). Therefore, geography and ecoregions may act as proxies for a variety of related physical and ecological variables that can influence production and biomass (Cinner et al. 2016)

This investigation proposes to answer the following questions: (1) Is there a useful baseline or benchmark for coral reef fish biomass to estimate reef fish biomass status for many Indian and Pacific Ocean reefs? (2) How variable and potentially different are B\&Bs when comparing remote reef areas, old and large high-compliance fisheries closures, biogeographic zones, and ecoregions? (3) How are B\&Bs influenced by environmental factors including distance to markets, primary productivity, reef area, coral cover, habitat, depth, waves, and solar energies (see Table 1)? To address these questions, we compiled fish biomass data and potentially influencing factors for $\sim 1000$ of the world's least disturbed reefs across the full range of reef latitudes and longitudes. These sites included old, large, high-compliance fisheries closures and remote reefs that are most likely to provide biomass data with the potential to uncover a range of broad-scale B\&Bs. 


\section{METHODS}

\subsection{Fish biomass inclusion criteria}

We used coral reef fish census data from a number of ecoregions and fit a number of criteria (see Table S1 in the Supplement at www.int-res.com/ articles/suppl/m612p167_supp.pdf). First, the studied fish communities were associated with hard bottom carbonate reefs. Second, locations had low fishing impacts and were categorized as highcompliance fisheries closures, based on the field biologist's investigations and knowledge of the site, or could be classified as a remote reef based on the distance to fisheries markets (Cinner et al. 2018). Criteria for inclusion was the biologist's perceived compliance of the closure management and that the reef had been closed to fishing for $>15 \mathrm{yr}$. These criteria may not be sufficient for large roaming apex predators (D'agata et al. 2016) but have been shown to represent points where benthicassociated reef fish biomasses were stable in previous age and size of closure studies (McClanahan et al. 2009). We classified the effectiveness of no-fishing restrictions based on a combination of legal management classifications and discussions with investigators who classified protected reef sites as either low- or high-compliance closures. Therefore, sites legally closed to fishing but where fishing was reported or observed by the investigator, informants, or published literature were considered lowcompliance and were not included in the final evaluation. We categorized the second category, namely remoteness, as being $>9 \mathrm{~h}$ travel distance from the nearest fish market using common fishing transportation methods $\left(20 \mathrm{~km} \mathrm{~h}^{-1}\right.$ at sea and $60 \mathrm{~km} \mathrm{~h}^{-1}$ on primary and $30 \mathrm{~km} \mathrm{~h}^{-1}$ on secondary roads) (Maire et al. 2016). This distance is generally near or above the travel distance where biomass, especially of site-associated benthic species, saturates (D'agata et al. 2016). Our third criterion was that all fish $>3 \mathrm{~cm}$ had to be counted in belt transects that covered $\geq 250 \mathrm{~m}^{2}$, sized, and identified at least to family level. We used this minimum transect size to reduce variability in sampling and the potential sampling-induced exclusion of large fishes that are often not observed in smaller or stationary transects (Samoilys \& Carlos 2000, McCauley et al. 2012).

We obtained data by contacting authors of published studies and from a public request for data that fit the above criteria placed on the Coral Reef List Server (http://coral.aoml.noaa.gov/mailman/listinfo/ coral-list). From these 2 sources and the above criteria, we obtained a total of 1031 Indian and Pacific reef sites from 18 observers, of which 160 were categorized as high-compliance fisheries closures and 871 as remote reef sites (see Table 2). We defined a site to include all fish censuses conducted within a $4 \mathrm{~km}^{2}$ buffer area under the same management and habitat classifications where all times and transects in that buffer were pooled to avoid pseudo-replication. We completed censuses between the years 2005 and 2016, and repeated census over a $1 \mathrm{yr}$ period were pooled after testing and finding a weak effect of sampling date $\left(r^{2}=0.05\right)$. The final site data ranged in latitude from $28.45^{\circ} \mathrm{N}$ (Hawaii) to $27.90^{\circ} \mathrm{S}$ (Rapa-Pitcairn marine ecoregion) and longitudes of $32.90^{\circ} \mathrm{E}$ (Delagoa-Northern Mozambique marine ecoregion) to $105.4^{\circ} \mathrm{W}$ (Easter Island). We categorized sites into 21 tropical ecoregions to evaluate the potential influence of biogeography on biomass (Spalding et al. 2007) (Fig. 1).

\subsection{Fish biomass}

We estimated reef fish biomass based on instantaneous visual counts where reef-associated fishes were identified to family or species level, numbers counted, and total lengths (TL) estimated and converted to weights (McClanahan \& Kaunda-Arara 1996, Kulbicki et al. 2005). We present biomass estimates as fish families that were consistently censused between observers while removing some taxa that are difficult to sample, like sharks, and transient or strictly plankton-feeding groups, such as Caesionidae (Table S1). Biomass was therefore based on reef fishes in 28 common coral reef families, excluding sharks. Exclusion of sharks is likely to have variable influence on the biomass between regions, remoteness, and histories of fishing (D'agata et al. 2016, Juhel et al. 2018).

\subsection{Anthropogenic influences}

\subsubsection{Human population counts}

We obtained human population counts for all sites from the Marine Socio-Environmental Covariates (MSEC) data set (Yeager et al. 2017). We obtained population counts within a radius of $20 \mathrm{~km}$ of each site for the year 2015, the most recently available population estimates at the time of analysis. 


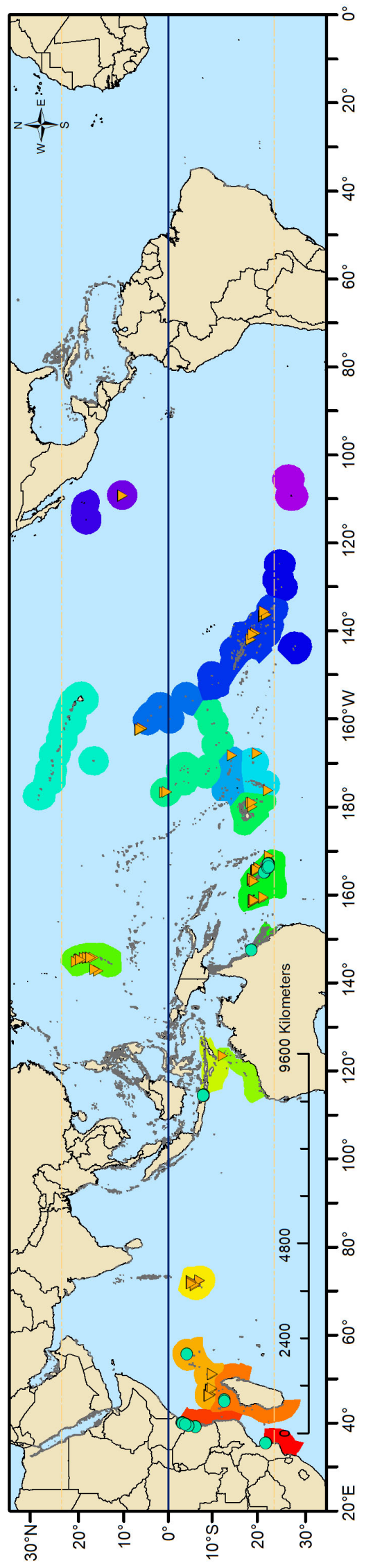

- High compliance closures, $n=160$

$\nabla$ Remote areas, $n=832$

Ecoregion

Delagoa, $n=8$

East African Coral Coast, $n=50$

Western and Northern Madagascar, $n=4$

Seychelles, $n=99$

Chagos, $n=33$

Lesser Sunda, $\mathrm{n}=28$

Exmouth to Broome, $n=4$

Mariana Islands, $\mathrm{n}=45$

Central and Southern Great Barrier Reef, $\mathrm{n}=15$

New Caledonia, $n=147$

Fiji Islands, $\mathrm{n}=44$

Phoenix/Tokelau/Northern Cook Islands, $n=4$

Hawaii, $n=192$

Tonga Islands, $\mathrm{n}=44$

Samoa Islands, $\mathrm{n}=10$

Line Islands, $n=93$

Tuamotus, $\mathrm{n}=42$

Rapa-Pitcairn, $\mathrm{n}=85$

Revillagigedos, $n=40$

Clipperton, $n=25$

Easter Island, $\mathrm{n}=20$

\subsubsection{Travel time and gravity to market and nearest population}

We computed travel times using a cost-distance algorithm that computes the least 'cost' (in minutes) of travelling between the site and the nearest major market and human habitation based on a regular raster grid (Maire et al. 2016). We calculated gravity by taking the population of the nearest major market (a geographically defined city or port) and inhabitants and dividing that by the squared travel time between the site and the market and human population.

\subsection{Environmental variables}

We expected that the environmental factors likely to influence fish or ecosystem production would include solar irradiance or photosynthetic active radiation (PAR), chlorophyll a (chl a) concentrations, net primary productivity (NPP), wave energy, reef area, habitat, depth, and coral cover. Additionally, we considered geographic position and ecoregion as proxies for various unmeasured environmental and biogeographic factors for each site.

\subsubsection{PAR and chl $a$}

We obtained PAR (Einsteins $\mathrm{m}^{-2} \mathrm{~d}^{-1}$ ) and chl a (mg $\mathrm{m}^{-3}$ ) data from GlobColour (www.globcolour.info/). We explored the time series data to determine the best window to evaluate the potential influence on studied coral reefs. We evaluated 2 time periods, one from near the beginning of the available time series (1998 for chl a and 2002 for PAR) to the mean period of the fish sampling and the second to the end of the available time series in 2016. The difference between these time window options was small for both chl $a$ and PAR (Pearson's correlation coefficient, $\mathrm{r}=0.96,0.88$, respectively) and we therefore picked the time to our sampling date.

Fig. 1. Ecoregions and study areas showing study sites distinguishing remote reef areas and highcompliance fisheries closures

\subsubsection{NPP, wave energy, and reef area}

We obtained NPP $\left(\mathrm{mg} \mathrm{C} \mathrm{m} \mathrm{m}^{-2} \mathrm{~d}^{-1}\right.$ ), wave energy $\left(\mathrm{kW} \mathrm{m}^{-1}\right)$, and reef area data from the MSEC data set (Yeager et al. 2017). We determined reef area $\left(\mathrm{km}^{2}\right)$ for reefs located within a radius of $20 \mathrm{~km}$ around our sites. 


\subsubsection{Habitat}

We determined habitats by examining Google Earth Pro images from the Millennium Coral Reef Mapping Project (MCRMP) hierarchical data. We examined each GPS point and categorizing them into the following categories: (1) the reef slope, which is typically on the deeper ocean side of a reef, where the reef slopes down into deeper water; (2) the crest, defined as the shallower section that joins a reef slope to the reef flat, which is typified by high wave energy; (3) reef flats, which were defined as typically horizontal and extending back from the reef crest for 10 s to 100s of m; and (4) lagoon/back reef habitat, where the continuous reef flat breaks up into patchier deeper reef environments sheltered from wave energy.

\subsubsection{Depth and coral cover}

We collected depths of the surveys from each observer and pooled them into the following categories: <4, 4-10, and $>10 \mathrm{~m}$ to account for broad differences in reef fish community structure attributable to a number of inter-linked, depth-related factors. Categories were necessary because observers recorded depths differently. Data providers also provided their coral cover data when available using methods following their own protocols.

\subsubsection{Geographic variables}

We imported the coordinates of the study sites into ArcGIS v.10.2.2 (ESRI) and converted them into a shape file. We super-imposed the resultant file on another shape file containing ecoregions outlined by Spalding et al. (2007). We used raw coordinates in some analyses, and in others we categorized the sites by ecoregions determined from this mapping procedure. We present some summary statistics for tropical and subtropical sites where the division between categories was above and below $23^{\circ} 26^{\prime} \mathrm{N}$ and S latitudes.

\subsection{Data analyses}

Based on our study goals and hypothesis, we tested for a number of significant effects as described in Table 1. These included tests for differences in biomass distributions in different unfished categories, and examining data for linear and unimodal relationships between fish biomass and covariates using ordinary least square regression. Additionally, we used applied linear variable selection, quantile regression, and multivariate ordination to test for envi- ronmental effects on biomass. Finally, we made pairwise comparisons of biomass between ecoregions.

\subsubsection{Fishing influences}

It is challenging to find and evaluate coral reefs with no fishing effects, as influences can exist both within legally protected areas and remote locations (Graham \& McClanahan 2013, D'agata et al. 2016, Maire et al. 2016, Gill et al. 2017). Protected fisheries closure areas, for example, often exist as islands within fished seascapes, and the accumulation of biomass can be influenced by the age, size, distance to fisheries markets, and compliance levels of the closures (Molloy et al. 2009, Cinner et al. 2018). Therefore, we divided closures into 2 groups where participants decided if they were high or low compliance. We removed all low-compliance closures from the analyses, such that only high-compliance closures were evaluated. In the case of remote reef areas, fishers, military, and other transient people may periodically fish during their visits. Yet, fishing pressure is likely to be reduced greatly as the distance to markets increases (Maire et al. 2016). The criteria for inclusion of sites reduced these possible effects, and testing the differences between high-compliance closures and remote reefs also allowed us to test the effect of the closure-island effect. Nevertheless, we evaluated 3 possible 'nuisance factors' - the age of the fisheries closures ( $>15 \mathrm{yr}$ ), size of fisheries closures, and travel time to fish markets - to determine if these factors might have influenced biomass estimates. We computed travel time, also defined as the least 'cost' (in minutes) of travelling between 2 locations on a regular raster grid, using a cost-distance algorithm (Cinner et al. 2016, Maire et al. 2016). We tested for possible effects of these 3 inclusion decisions using linear and unimodal relationships between the age and size of the closures and travel time on the total biomass.

\subsubsection{Tests of data distributions and significance}

We tested sites for various aspects of variability associated with methods and observers, outliers, and inclusion of fish groups. We found that the observer's biomass estimates were strongly related to the ecoregions they studied $\left(\mathrm{R}^{2}=0.75\right)$ and hence were not considered as a predictor of biomass in the analysis (Table S1). We therefore conducted a multivariate outlier analysis of biomass values versus latitude and longitude coordinates, using JMP v.13 software (Sall et al. 2001). We analyzed data for closures and remote reef categories separately due to differences 
Table 1. Goals, hypothesis, data sources, analysis and methods used in the evaluation of fishery closure benchmarks and remote reef baselines in the Indo-Pacific Ocean basins. BIC: Bayesian information criterion; fishery closure: no fishing for $>15$ yr; MCRMP: Millennium Coral Reef Mapping Project; NPP: net primary productivity; PAR: photosynthetically active radiation

\begin{tabular}{|c|c|c|c|c|}
\hline Goal & Hypothesis & Data source/attributes & Analysis & Methods \\
\hline $\begin{array}{l}\text { Determine whether } \\
\text { there are differences } \\
\text { between fishery } \\
\text { closure benchmarks } \\
\text { and wilderness } \\
\text { baselines }\end{array}$ & $\begin{array}{l}\text { Fish biomass and } \\
\text { environmental } \\
\text { variables in fishery } \\
\text { closures and remote } \\
\text { areas are signifi- } \\
\text { cantly different }\end{array}$ & $\begin{array}{l}\text { Fish biomass in fishery } \\
\text { closures and remote areas } \\
\text { from field surveys, human } \\
\text { influences (Yeager et al. } \\
\text { 2017), environmental } \\
\text { variables (Yeager et al. } \\
\text { 2017, GlobColour www. } \\
\text { globcolour.info/) and } \\
\text { habitat (MCRMP) }\end{array}$ & $\begin{array}{l}\text { Tests of data } \\
\text { distributions }\end{array}$ & $\begin{array}{l}\text { Student's t-tests, } \\
\text { empirical cumu- } \\
\text { lative frequen- } \\
\text { cies and butter- } \\
\text { fly plots }\end{array}$ \\
\hline $\begin{array}{l}\text { Test for influence of } \\
\text { humans, environ- } \\
\text { mental, and habitat on } \\
\text { biomass benchmarks } \\
\text { and baselines }\end{array}$ & $\begin{array}{l}\text { Fish biomass is } \\
\text { driven by human } \\
\text { influences, environ- } \\
\text { mental variables and } \\
\text { habitat }\end{array}$ & $\begin{array}{l}\text { Fish biomass from field } \\
\text { surveys, human influences } \\
\text { (Yeager et al. 2017), } \\
\text { environmental variables } \\
\text { (Yeager et al. 2017, } \\
\text { GlobColour) and habitat } \\
\text { (MCRMP) }\end{array}$ & $\begin{array}{l}\text { Linear/unimodal } \\
\text { relationships } \\
\text { between biomass } \\
\text { and covariates }\end{array}$ & $\begin{array}{l}\text { Best fit linear } \\
\text { and } 2 \text { nd order } \\
\text { polynomial } \\
\text { equations }\end{array}$ \\
\hline $\begin{array}{l}\text { Find the best } \\
\text { predictors }\end{array}$ & $\begin{array}{l}\text { Environmental and } \\
\text { human variables } \\
\text { differ in the strength } \\
\text { of their co-linearity } \\
\text { and influence }\end{array}$ & $\begin{array}{l}\text { Fish biomass from field } \\
\text { surveys, human influences } \\
\text { (Yeager et al. 2017), } \\
\text { environmental variables } \\
\text { (Yeager et al. 2017, } \\
\text { GlobColour) and habitat } \\
\text { (MCRMP) }\end{array}$ & $\begin{array}{l}\text { Linear associa- } \\
\text { tions and variable } \\
\text { selection }\end{array}$ & $\begin{array}{l}\text { Forward step- } \\
\text { wise regression } \\
\text { with BIC stop- } \\
\text { ping rules }\end{array}$ \\
\hline $\begin{array}{l}\text { Determine if respon- } \\
\text { ses are dependent on } \\
\text { portions of the data } \\
\text { distribution }\end{array}$ & $\begin{array}{l}\text { Fish biomass re- } \\
\text { sponses are depen- } \\
\text { dent on the portions } \\
\text { of the biomass distri- } \\
\text { bution (quantiles) }\end{array}$ & $\begin{array}{l}\text { Fish biomass from field } \\
\text { surveys, covariates se- } \\
\text { lected following forward } \\
\text { stepwise regression with } \\
\text { BIC stopping rules }\end{array}$ & $\begin{array}{l}\text { Linear relation- } \\
\text { ships between bio- } \\
\text { mass and selected } \\
\text { covariates at } \\
\text { various quantiles }\end{array}$ & $\begin{array}{l}\text { Quantile } \\
\text { regression }\end{array}$ \\
\hline $\begin{array}{l}\text { Test for geographical } \\
\text { effects on benchmark } \\
\text { and baseline biomass }\end{array}$ & $\begin{array}{l}\text { Fish biomass is } \\
\text { driven by geographic } \\
\text { effects }\end{array}$ & $\begin{array}{l}\text { Fish biomass from field } \\
\text { surveys of authors, lati- } \\
\text { tude, longitude, eco- } \\
\text { regions (Spalding et al. } \\
\text { 2007) }\end{array}$ & $\begin{array}{l}\text { Linear associat- } \\
\text { ions and variable } \\
\text { selection }\end{array}$ & $\begin{array}{l}\text { Forward step- } \\
\text { wise regression } \\
\text { with BIC stop- } \\
\text { ping rules }\end{array}$ \\
\hline $\begin{array}{l}\text { Test for geographical } \\
\text { effects after removing } \\
\text { environmental and } \\
\text { human influences }\end{array}$ & $\begin{array}{l}\text { Fish biomass is } \\
\text { driven by geographic } \\
\text { effects independent } \\
\text { of environmental and } \\
\text { human influences }\end{array}$ & $\begin{array}{l}\text { Residuals from human } \\
\text { influences, environmental } \\
\text { and habitat variables vs. } \\
\text { geographic traits }\end{array}$ & $\begin{array}{l}\text { Linear associa- } \\
\text { tions and variable } \\
\text { selection }\end{array}$ & $\begin{array}{l}\text { Forward step- } \\
\text { wise regression } \\
\text { with BIC stop- } \\
\text { ping rules }\end{array}$ \\
\hline $\begin{array}{l}\text { Test for effects of } \\
\text { between-ecoregion } \\
\text { environmental } \\
\text { influences }\end{array}$ & $\begin{array}{l}\text { Variability between } \\
\text { ecoregions is driven } \\
\text { by ecoregions, habi- } \\
\text { tat, NPP and PAR }\end{array}$ & $\begin{array}{l}\text { Fish biomass from field } \\
\text { surveys of authors vs. } \\
\text { ecoregions (Spalding et al. } \\
\text { 2007), habitat (MCRMP), } \\
\text { NPP (Yeager et al. 2017) } \\
\text { and PAR (GlobColour) }\end{array}$ & $\begin{array}{l}\text { Multivariate } \\
\text { ordination }\end{array}$ & $\begin{array}{l}\text { Principal } \\
\text { component } \\
\text { analysis }\end{array}$ \\
\hline $\begin{array}{l}\text { Test for differences } \\
\text { in biomass between } \\
\text { ecoregions }\end{array}$ & $\begin{array}{l}\text { Ecoregions differ in } \\
\text { their biomass }\end{array}$ & $\begin{array}{l}\text { Fish biomass from field } \\
\text { surveys of authors vs. eco- } \\
\text { regions (Spalding et al. } \\
\text { 2007) }\end{array}$ & $\begin{array}{l}\text { Pairwise fishery } \\
\text { closure compari- } \\
\text { sons between } \\
\text { ecoregions }\end{array}$ & $\begin{array}{l}\text { Tukey's honest } \\
\text { significant } \\
\text { difference }\end{array}$ \\
\hline
\end{tabular}


in their variances. Examination of outliers used a number of variables rather than the tail ends of biomass distributions, which is used in univariate outlier analyses. Because we did not want B\&Bs to be influenced by either unusually low or high values, we evaluated the Mahalanobis distances of each site, and values greater than the upper control limits were detected, defined as outliers, and excluded from further analyses (Mason \& Young 2002). We detected and removed 39 sites with both low and high values. Thereafter, we calculated biomass means, medians, standard deviations, and 95\% confidence intervals for all sites and classifications. Raw data was rightskewed and therefore we tested the raw and $\log _{\mathrm{e}}$ biomass values for normality using KolmogorovSmirnov tests. We found that $\log _{\mathrm{e}}$ transformed data were a better fit to normality and therefore used these transformed data in all statistical testing.

We evaluated biomass variability in B\&Bs based on our 2 classifications: closures and remote reefs. We plotted cumulative frequency distributions to examine the distribution of the data for the classifications and all sites combined. We conducted Student's $t$-tests to determine differences in biomass and environmental variables between closures and remote reef sites. Further, we conducted pairwise Tukey's honest significant comparisons between ecoregions using the $\log _{\mathrm{e}}$ biomass. To account for differences in environment and habitat variables, we also made these comparisons using residuals from a statistically significant environmental and habitat variable regression relationships (JMP v.13.0).

\subsubsection{Bivariate relationships and forward stepwise regression}

We evaluated fits of potential relationships (linear and $2^{\text {nd }}$ order polynomial) for $\log _{\mathrm{e}}$ transformed biomass versus the above environmental parameters (JMP v.13.0). We excluded subtropical sites $(n=332)$ because there were no significant relationships between $\log _{e}$ biomass and human influences or environmental variables. We undertook forward stepwise regressions of closures, remote reefs, and both reef categories combined to determine the strongest of the 21 studied factors (JMP v.13.0). Furthermore, we used a forward stepwise regression procedure to calculate residuals of significant environment variables $(p<0.05)$ to test for differences in geography that were independent of the environmental variables. Sample sizes were smaller when analyzing residuals versus geographic variables because some sites lacked all environmental variables.
Selection of variables in all forward stepwise regression analyses was based on Bayesian information criterion (BIC). We evaluated the variables of depth, habitat, ecoregion, and travel time using a hierarchical approach where variables were grouped to maximize differences in means (JMP v.13.0).

\subsubsection{Quantile regression}

To further evaluate variation and the validity of ordinary least squares regression (OLS), we conducted linear quantile regressions for biomass versus variables selected in the forward stepwise regression (PAR, NPP, and coral cover) in R v.3.4.2 (R Development Core Team 2018) using the 'quantreg' package v.5.36 (Koenker 2018). This analytic method allowed us to examine covariate relationships for distinct portions of the biomass distributions. These portions, known as Tau values, were set at intervals of 0.1 from 0.1 to 0.9 in order to estimate relationships between biomass and PAR, NPP, and coral cover for these specific quantiles. We presented intercept and slope coefficients from quantile regressions graphically using the 'plot()' function in R. To test for geographic patterns in responses, we extracted the residuals of estimated quantile regressions with the highest slopes for PAR and NPP (using the R 'residuals()' function) and plotted them against relative latitude.

\subsubsection{Principal component analyses}

We tested for large-scale distribution patterns with environmental, habitat, and biomass metrics using principal component analysis (PCA). We conducted the PCA using 'FactoMineR' package v.1.38, (Lê et al. 2008) and visualized using 'factoextra' package v.1.0.5 in R v.3.4.2 (Kassambara 2017). The variables we included in the PCA were those identified as significant by the forward stepwise regression procedure described above. We added habitat and ecoregions to the PCA as supplementary variable vectors.

\section{RESULTS}

\subsection{Biomass estimates}

Mean $( \pm \mathrm{SD})$ biomass of the 992 selected reef sites was $1380 \pm 1330 \mathrm{~kg} \mathrm{ha}{ }^{-1}$ with a $95 \%$ confidence interval on the mean between 1300 (lower CI; LCI)

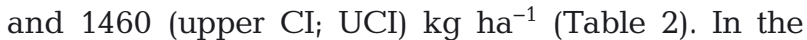


tropics, high-compliance no-take closures had a lower biomass of $740(660,810) \mathrm{kg} \mathrm{ha}^{-1}$, compared to remote reefs $1870(1730,2000) \mathrm{kg} \mathrm{ha}^{-1}$. A majority of subtropical sites were located in remote reefs $(\mathrm{n}=$ $329)$ rather than closure $(n=3)$ locations and biomass was $950(860,1040) \mathrm{kg} \mathrm{ha}^{-1}$.

The raw reef fish biomass data had positive skewness and kurtosis, indicating centralized and right skew in the distributions that changed after $\log _{\mathrm{e}}$ transformations. Therefore, median values better express the most common biomass without the influence of the skew in the distributions. For example, median biomasses in the tropics were overall lower at $655 \mathrm{~kg} \mathrm{ha}^{-1}$ for closures, $1370 \mathrm{~kg} \mathrm{ha}^{-1}$ for remote reefs, and $1110 \mathrm{~kg} \mathrm{ha}^{-1}$ for all sites in the tropics. Median fish biomass was $704 \mathrm{~kg} \mathrm{ha}^{-1}$ for the subtropical sites. Cumulative frequency distributions of the fish biomass indicate little overlap between remote and closure sites (Fig. 2).

\subsection{Differences between remote reefs and fisheries closures}

Remote reefs and fisheries closures differed in a number of factors, of which travel times to markets was the largest. Closures had mean $( \pm \mathrm{SD})$ travel times of $2.3 \pm 1.3 \mathrm{~h}$ whereas remote reef sites had order-ofmagnitude higher travel times of $38.8 \pm 30.3 \mathrm{~h}$ (Table 3 ). This travel distance, which is often a distance from land, was also reflected in the chl a concentrations and NPP; closures had around twice the chl $a$ and NPP than remote reef sites. Nearshore closures had around $5 \%$ higher coral cover than remote reef areas.

\subsection{Biomass correlates}

\subsubsection{Size, age, and location parameters}

There was no significant relationship between the size of the no-take fisheries closures and biomass. The age of fisheries closures ranged from 15 to $48 \mathrm{yr}$ and biomass increased weakly with closure time $\left(\mathrm{r}^{2}=\right.$ 0.07) (Table 4). Biomasses declined weakly with travel time to markets for closures $\left(\mathrm{r}^{2}=0.02\right)$ but not remote reefs. None of these variables were chosen in the forward stepwise regression procedure.

\subsubsection{Environment and habitat variable associations}

Associations with environmental variables varied with the type of regression and biomass category.
Based on OLS regression, biomass in closures was positively associated, in declining predictive strength, with PAR, reef area, time since fishing closure, gravity to nearest market, NPP, and the human population within $20 \mathrm{~km}$ (Figs. 3 \& S1, Table S2). Negative relationships, in declining strength, were wave energy, travel time to nearest market, gravity to nearest human population, and relative latitude. In remote reef sites, wave energy and hard coral were positively associated and chl a was negatively associated with biomass. Habitat and depth were categorical variables and we found that biomass was higher in lagoons and slopes than flats and crests (Fig. 4). Similarly, biomass was higher in $>10$ and $4-10 \mathrm{~m}$ than in the 0-4 $\mathrm{m}$ depth categories.

Stepwise regressions reduced the number of significant variables for biomass in closures to PAR, NPP, wave energy, and depth (when the depth category was included; Table 4). The direction of NPP also changed from positive to negative by the stepwise procedure. In remote reefs, chosen stepwise variables included positive associations with travel time to nearest market, NPP, population within $20 \mathrm{~km}$, depth, coral cover, and longitude, while travel time to nearest population was negatively associated with biomass. When evaluating for possible interactions, longitude and NPP were significant for closures, and planetocentric longitude and travel time to the nearest market for remote reefs. Finally, the best models indicate that having just geographic coordinates can be useful for estimating biomass in closures but not remote reef sites because environmental variables contribute most of remote biomass variance (Table 5). Evaluating all variables together in all tropical sites confirmed the importance of remoteness, NPP, habitat, coral cover, $\mathrm{PAR}$, and the interaction between remoteness and PAR, with their combined influence predicting $30 \%$ of the variance (Table 6 ).

Quantile regressions of the biomass portions associations with PAR, NPP, and coral cover indicate that responses were variable depending on the quantiles examined (see Figs. 5-7). When evaluating all sites combined, the intercepts and slopes generally rose for all 3 variables with exception of the intercepts for PAR, which was constant and declined slightly in the highest quantiles (Fig. 5). Remote and high-compliance closure quantiles differed in their re-sponses to the 3 environmental variables. For example, in the case of NPP and PAR, the remote reef sites displayed an increase in slopes while closures displayed more stable slopes with increasing biomass quantiles. Intercepts of the quantile relationships increased in both closures and 
Table 2. Summary statistics of total biomass in remote reef and high-compliance fisheries closure areas. Includes mean $\pm \mathrm{SD}$, median, standard deviation (SD), $95 \%$ confidence intervals (CI; L: lower; U: upper), and sample sizes. Tests of normality were based on raw data and $\log _{e}(\mathrm{ln})$ transformed data. COV: coefficient of variation. KS: Kolmogorov-Smirnov values as test of normality

\begin{tabular}{|c|c|c|c|c|c|}
\hline & All sites & Tropics & $\begin{array}{l}\text { Subtropics } \\
\text { remote reefs }\end{array}$ & $\begin{array}{l}\text { Tropics } \\
\text { remote reefs }\end{array}$ & $\begin{array}{c}\text { Tropics } \\
\text { high compliance }\end{array}$ \\
\hline Sample size (n) & 992 & 660 & 329 & 503 & 157 \\
\hline Mean \pm SD & $1380.6 \pm 1328.3$ & $1598.5 \pm 1467.8$ & $947.3 \pm 846.1$ & $1867.7 \pm 1567.2$ & $736.1 \pm 464.2$ \\
\hline $\mathrm{COV}$ & 96.2 & 91.8 & 89.3 & 83.9 & 63.1 \\
\hline $95 \%$ CI $(\mathrm{L}, \mathrm{U})$ & $1297.8,1463.4$ & $856.4,1038.4$ & $855.5,1039.0$ & $1730.4,2004.9$ & $662.9,809.3$ \\
\hline Median & 948.0 & 1108.5 & 704.9 & 1370.6 & 655.4 \\
\hline $95 \%$ CI (L, U) & $878.7,1020.0$ & $1021.5,1236.6$ & $645.6,782.5$ & $1274.6,1488.4$ & $594.7,787.5$ \\
\hline Kurtosis & 4.0 & 7.8 & 7.7 & 1.3 & 0.8 \\
\hline Skewness & 1.9 & 2.3 & 2.3 & 1.4 & 0.8 \\
\hline KS & 0.170 & 0.174 & 0.151 & 0.151 & 0.077 \\
\hline p-value & 0.0001 & 0.0001 & 0.0001 & 0.0001 & 0.033 \\
\hline \multicolumn{6}{|c|}{ (b) Total biomass $\left(\mathrm{kg} \mathrm{ha}^{-1}\right)$ statistics in remote reef areas across habitat categories in tropics and subtropics } \\
\hline & Lagoon/back reef & Crest & Slope & Lagoon/back reef & Slope \\
\hline Sample size & 100 & 16 & 387 & 98.0 & 231.0 \\
\hline Mean $\pm \mathrm{SD}$ & $1762.5 \pm 1581.1$ & $1101.6 \pm 1304.0$ & $1926.5 \pm 1567.2$ & $786.5 \pm 672.3$ & $1015.5 \pm 902.5$ \\
\hline $\mathrm{COV}$ & 89.7 & 118.4 & 81.4 & 85.5 & 88.9 \\
\hline $95 \%$ CI $(\mathrm{L}, \mathrm{U})$ & $1448.7,2076.2$ & $406.7,1796.4$ & $1769.9,2083.1$ & $651.7,921.3$ & $898.5,1132.5$ \\
\hline Median & 1162.1 & 750.2 & 1455.9 & 614.1 & 765.7 \\
\hline $95 \%$ CI (L, U) & $920.2,1559.1$ & $201.2,1355.6$ & $1304.9,1545.5$ & $522.3,699.9$ & $688.37,905.5$ \\
\hline Kurtosis & 1.3 & 6.4 & 1.4 & 3.0 & 7.5 \\
\hline Skewness & 1.4 & 2.3 & 1.4 & 1.7 & 2.3 \\
\hline $\mathrm{KS}$ & 0.163 & 0.224 & 0.149 & 0.184 & 0.147 \\
\hline $\mathrm{p}$-value & 0.0001 & 0.04 & 0.0001 & 0.0001 & 0.0001 \\
\hline \multirow{2}{*}{\multicolumn{6}{|c|}{$\begin{array}{l}\text { (c) Biomass }\left(\mathrm{kg} \mathrm{ha}^{-1}\right) \text { statistics of high-compliance fisheries closures in the tropics for coral reef habitat categories. NS: not } \\
\text { significant } \\
\qquad \text { Lagoon/back reef }\end{array}$}} \\
\hline & & & & & \\
\hline Sample size & 71 & 10 & 7 & 69 & \\
\hline Mean $\pm \mathrm{SD}$ & $897.2 \pm 457.1$ & $621.2 \pm 489.4$ & $676.0 \pm 224.9$ & $593.1 \pm 439.2$ & \\
\hline $\mathrm{COV}$ & 50.9 & 78.8 & 33.3 & 74.1 & \\
\hline $95 \%$ CI $(\mathrm{L}, \mathrm{U})$ & $789.0,1005.4$ & $271.1,971.2$ & $468.0,884.0$ & $487.6,698.6$ & \\
\hline Median & 899.9 & 561.4 & 596.6 & 518.6 & \\
\hline $95 \%$ CI $(\mathrm{L}, \mathrm{U})$ & $772.3,1002.8$ & $222.6,952.3$ & $471.0,936.6$ & $378.4,627.5$ & \\
\hline Kurtosis & -0.7 & 0.2 & -1.2 & 5.4 & \\
\hline Skewness & 0.2 & 0.6 & 0.1 & 1.7 & \\
\hline KS & 0.066 & 0.127 & 0.209 & 0.115 & \\
\hline p-value & NS & NS & NS & 0.03 & \\
\hline \multirow{2}{*}{\multicolumn{6}{|c|}{$\begin{array}{l}\text { (d) Ratio of total biomass }\left(\mathrm{kg} \mathrm{ha}^{-1}\right) \text { in high-compliance closures to remote reef areas across } 3 \text { coral reef habitat categories } \\
\begin{array}{llll}\text { Mean biomass } & \text { Lagoon/back reef } & \text { Crest } & \text { Slope }\end{array}\end{array}$}} \\
\hline & & & & & \\
\hline \multirow{2}{*}{\multicolumn{2}{|c|}{$\begin{array}{l}\text { High-compliance closures } \\
\text { Remote reefs }\end{array}$}} & 897.2 & 676.0 & 593.1 & \\
\hline & & 1762.5 & 1101.6 & 1926.5 & \\
\hline \multicolumn{2}{|c|}{ Ratio $\left(\frac{\text { High compliance closures }}{\text { Remote areas }}\right)$} & 0.51 & 0.61 & 0.31 & \\
\hline
\end{tabular}

remote reefs for NPP (Fig. 6). In remote reefs, intercepts for PAR declined at the highest biomass quantiles. Coral cover-biomass responses are complex in that slopes are unimodal in remote reefs, rising and falling with a peak at the $60^{\text {th }}$ percentile. Closures, in constant, were more stable (Fig. 7). Intercepts of biomass-coral cover relationships rose in both remote and closure reefs. 


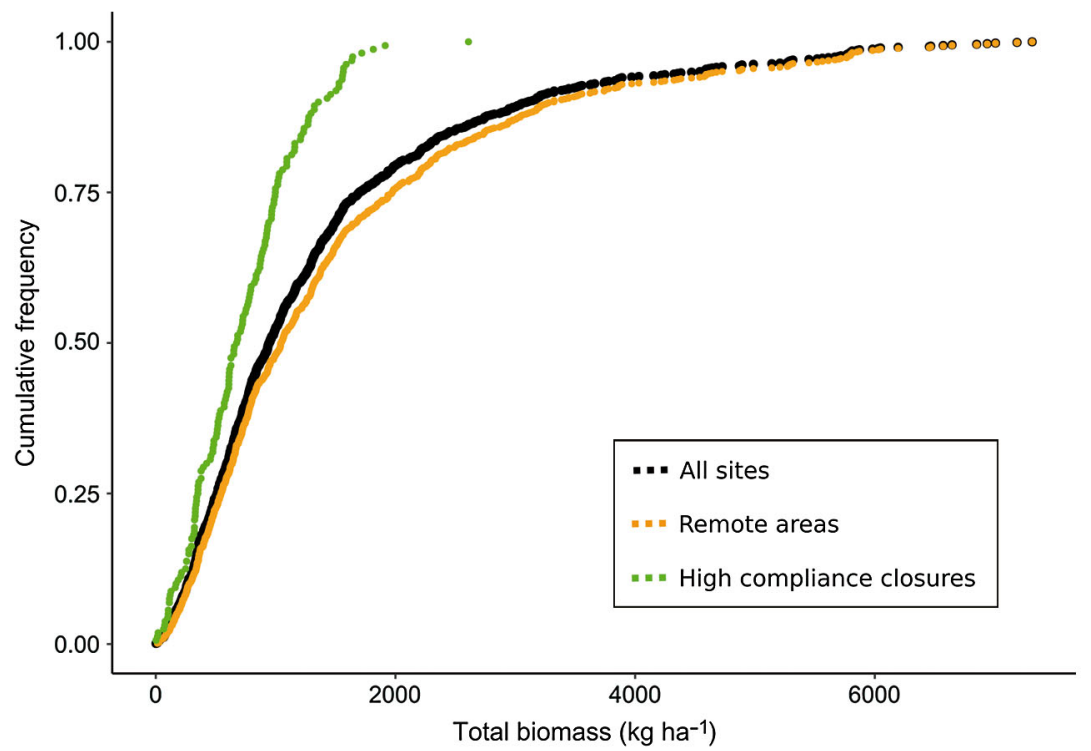

Fig. 2. Frequency distributions of fish biomass in remote reef areas, highcompliance fisheries closure areas, and all sites combined

Residuals of NPP and PAR-biomass relationships at the $90^{\text {th }}$ percentiles showed high variability with relative latitude, indicating no clear geographic pattern in the location of high biomass sites (Fig. 8). Rather, high biomass sites had high variation in residuals, which is also reflected in their high coefficients of variation (Table 2).

\subsubsection{Geography}

Latitude and longitude by themselves and their interaction explained $23 \%$ of the variance in closures (Table 5). When evaluating ecoregions, latitude and longitude by themselves were weak predictors of biomass and were removed by the stepwise regression procedure in favor of remoteness and differences between some ecoregions (Table 7a). Remoteness, when combined with differences between ecoregions, explained $36 \%$ of the variance in biomass. The 17 studied ecoregions produced 7 significant pooled groups that overlapped in their variance and inclusion of ecoregions. However, when evaluating geographic variables using the residuals of the environment and habitat relationships for the 10 regions, only 2 significant groups were produced, and these predicted only $8 \%$ of the variance (Table $7 \mathrm{~b}$ ).

Pairwise testing of differences in raw biomass between the 17 ecoregions produced 2 significantly different groups but only 3 ecoregions that were contained in 1 of these 2 groups. These 3 ecoregions

Table 3. Tests for differences between remote reef areas and high-compliance fisheries closures for human influences, habitat, and environmental variables in the tropics of Indo-Pacific Ocean basins

\begin{tabular}{|c|c|c|c|c|c|}
\hline Variable & Remoteness & $\mathrm{N}$ & Mean \pm SD & $t$-value & $\mathrm{p}$-value \\
\hline $\begin{array}{l}\text { Travel time to nearest } \\
\text { market }(\mathrm{h})\end{array}$ & $\begin{array}{l}\text { Remote reef areas } \\
\text { High-compliance closures }\end{array}$ & $\begin{array}{l}503 \\
157\end{array}$ & $\begin{aligned} 38.8 & \pm 30.3 \\
2.3 & \pm 1.3\end{aligned}$ & 26.9 & 0.0001 \\
\hline $\begin{array}{l}\text { Travel time to nearest } \\
\text { human population (h) }\end{array}$ & $\begin{array}{l}\text { Remote reef areas } \\
\text { High-compliance closures }\end{array}$ & $\begin{array}{l}503 \\
157\end{array}$ & $\begin{array}{c}11.9 \pm 13.8 \\
0.6 \pm 1.1\end{array}$ & 18.2 & 0.0001 \\
\hline Gravity to nearest market & $\begin{array}{l}\text { Remote reef areas } \\
\text { High-compliance closures }\end{array}$ & $\begin{array}{l}503 \\
157\end{array}$ & $\begin{array}{c}0.1 \pm 0.1 \\
171.0 \pm 390.0\end{array}$ & -5.5 & 0.0001 \\
\hline $\begin{array}{l}\text { Gravity to nearest } \\
\text { human population }\end{array}$ & $\begin{array}{l}\text { Remote reef areas } \\
\text { High-compliance closures }\end{array}$ & $\begin{array}{l}503 \\
157\end{array}$ & $\begin{aligned} 0.1 & \pm 0.2 \\
181.0 & \pm 619.0\end{aligned}$ & -3.7 & 0.0001 \\
\hline $\begin{array}{l}\text { Population within a } \\
\text { distance of } 20 \mathrm{~km}\end{array}$ & $\begin{array}{l}\text { Remote reef areas } \\
\text { High-compliance closures }\end{array}$ & $\begin{array}{l}502 \\
157\end{array}$ & $\begin{aligned} 209.0 & \pm 451.0 \\
259015.0 & \pm 395529.0\end{aligned}$ & -8.2 & 0.0001 \\
\hline $\begin{array}{l}\text { Reef area within a distance } \\
\text { of } 20 \mathrm{~km}\left(\mathrm{~km}^{-2}\right)\end{array}$ & $\begin{array}{l}\text { Remote reef areas } \\
\text { High-compliance closures }\end{array}$ & $\begin{array}{l}502 \\
157\end{array}$ & $\begin{array}{l}50.1 \pm 48.1 \\
91.4 \pm 54.7\end{array}$ & -8.5 & 0.0001 \\
\hline Hard coral (\%) & $\begin{array}{l}\text { Remote reef areas } \\
\text { High-compliance closures }\end{array}$ & $\begin{array}{l}362 \\
105\end{array}$ & $\begin{array}{l}29.4 \pm 21.0 \\
34.6 \pm 19.0\end{array}$ & -2.42 & 0.0170 \\
\hline $\begin{array}{l}\text { Photosynthetically active } \\
\text { radiation }\left(\mathrm{E} \mathrm{m}^{-2} \mathrm{~d}^{-1}\right)\end{array}$ & $\begin{array}{l}\text { Remote reef areas } \\
\text { High-compliance closures }\end{array}$ & $\begin{array}{l}501 \\
157\end{array}$ & $\begin{array}{l}42.9 \pm 2.5 \\
44.8 \pm 2.6\end{array}$ & -7.9 & 0.0001 \\
\hline Chl a $\left(\mathrm{mg} \mathrm{m}^{-3}\right)$ & $\begin{array}{l}\text { Remote reef areas } \\
\text { High-compliance closures }\end{array}$ & $\begin{array}{l}501 \\
157\end{array}$ & $\begin{array}{l}0.3 \pm 0.2 \\
0.7 \pm 0.3\end{array}$ & -15.3 & 0.0001 \\
\hline $\begin{array}{l}\text { Net primary productivity } \\
\left(\mathrm{mg} \mathrm{C} \mathrm{m}^{-2} \mathrm{~d}^{-1}\right)\end{array}$ & $\begin{array}{l}\text { Remote reef areas } \\
\text { High-compliance closures }\end{array}$ & $\begin{array}{l}502 \\
157\end{array}$ & $\begin{array}{r}654.0 \pm 288.0 \\
1056.0 \pm 286.0\end{array}$ & -15.3 & 0.0001 \\
\hline Wave energy $\left(\mathrm{kW} \mathrm{m}^{-1}\right)$ & $\begin{array}{l}\text { Remote reef areas } \\
\text { High-compliance closures }\end{array}$ & $\begin{array}{l}502 \\
153\end{array}$ & $\begin{array}{c}22.2 \pm 12.4 \\
6.6 \pm 6.5\end{array}$ & 20.5 & 0.0001 \\
\hline
\end{tabular}




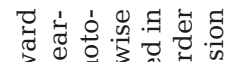

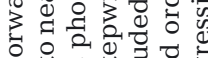

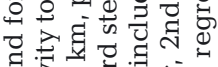

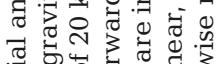

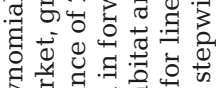

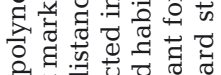

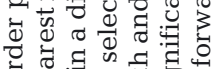
of

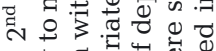

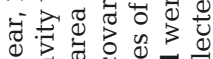

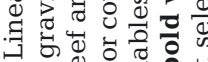

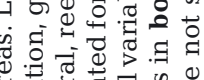

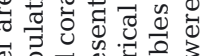

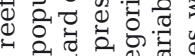
Q

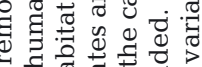

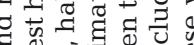

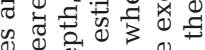
$\exists$ : Uै 记

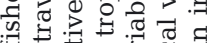

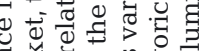
व

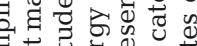

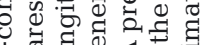
i

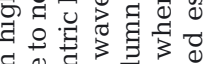
द्व

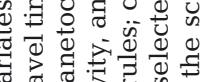

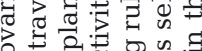

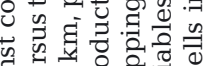
告

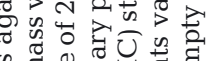
क : \& :

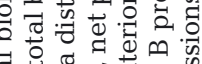

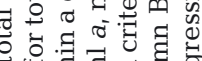

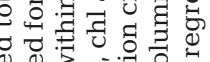

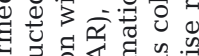

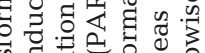

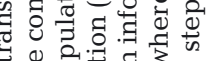

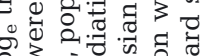

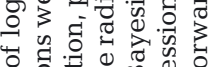

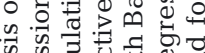

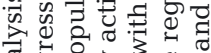

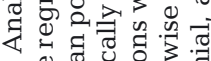

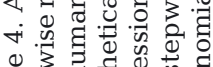

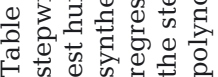

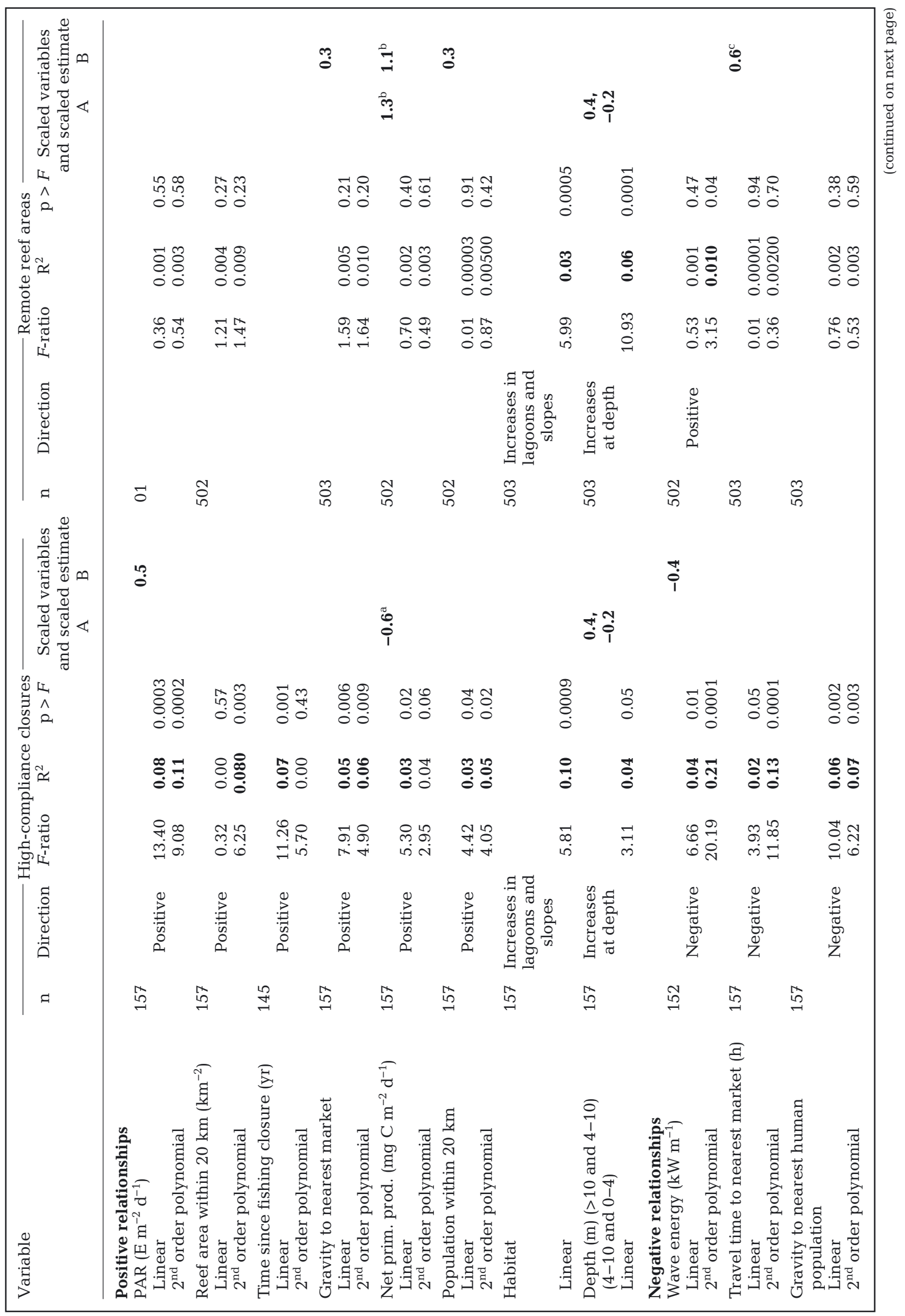




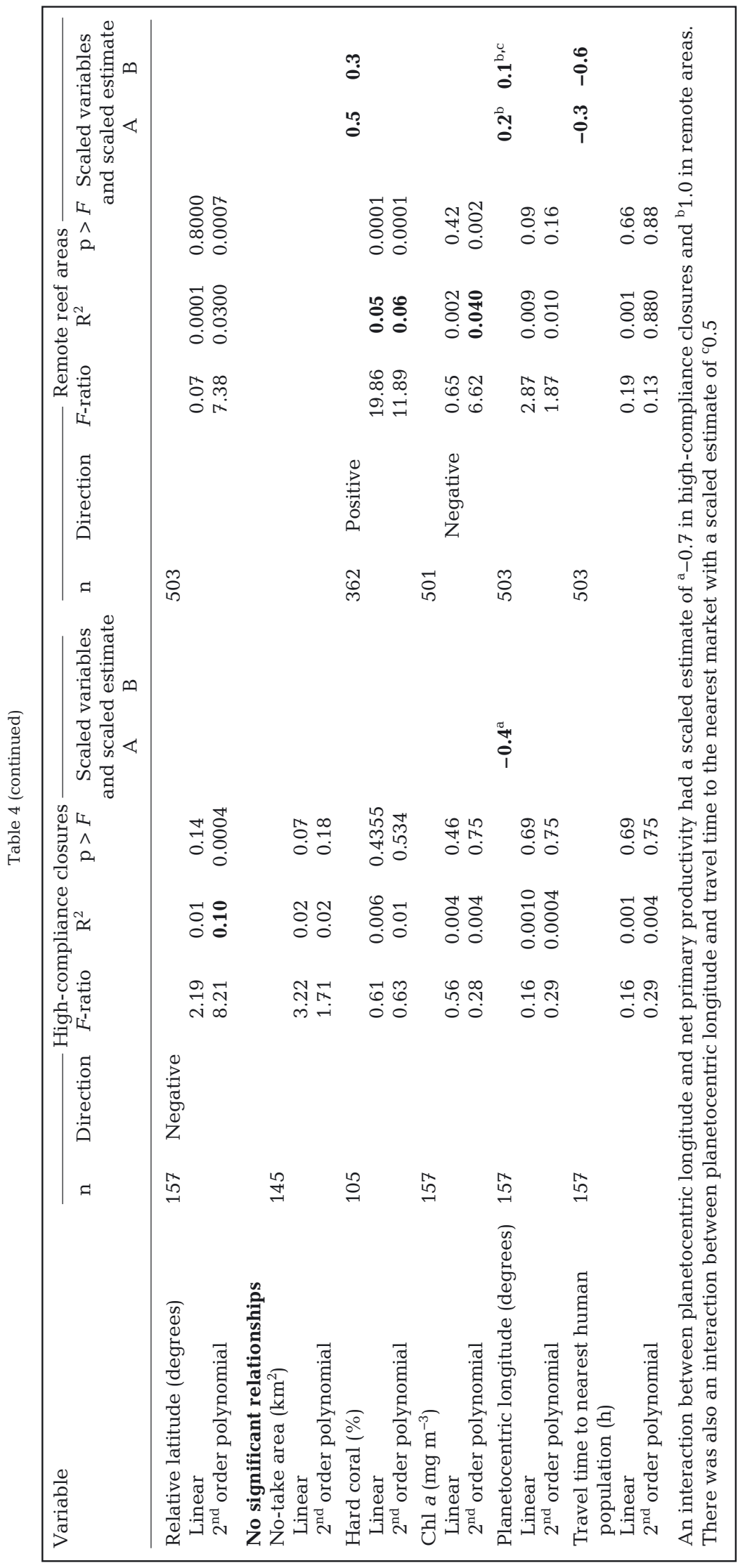

were southern and central Great Barrier Reef and New Caledonia, which were in group A only, while Marina Islands were only in group B. However, Differences between these groups were not large, with the first cluster (A) having a mean biomass (LCI, UCI) of 1662 (1544, 1780) $\mathrm{kg} \mathrm{ha}^{-1}$ and the other (B) of 1542 $(1417,1667) \mathrm{kg} \mathrm{ha}^{-1}$ (Table 8a). Using residuals from habitat and environmental influences reduced the analysis to 10 ecoregions (Table 8b). Results were similar in that the central and southern Great Barrier Reef and Mariana Islands were in separate groups but biomass differences were, again, small at 1930 $(1781,2084)$ and $1880(1733,2028) \mathrm{kg}$ $\mathrm{ha}^{-1}$ (Table $8 \mathrm{~b}$ ). Finally, the proximity of ecoregions did not clearly distinguish groups before removing environment and habitat influences. For example, the highest biomass locations of Chagos, New Caledonia, and Clipperton Islands were separated by large distances. In contrast, the lowest biomasses were in the remote Mariana Islands and Lesser Sunda.

\subsubsection{Multivariate analysis}

PCA of the environment and habitat factors showed high overlap between ecoregions (Fig. 9). Nevertheless, the first axis separated ecoregions along a low to high PAR and NPP axes that started in the remote Pacific and ended in East Africa. The second axis separated sites by coral cover. Fish biomass was intermediate between these 2 axes of coral and production metrics. This axis indicated that the higher variation in these variables were found in reefs from the Pacific to Seychelles. Notably, some Indian Ocean ecoregions and Clipperton Atoll in the Eastern Pacific had higher biomass than some Pacific Islands. The coefficients of variation of biomass of both closures and remote reefs in these ecoregions were generally high at 91.8 and $85.7 \%$ for both raw and residual groups, respectively. 

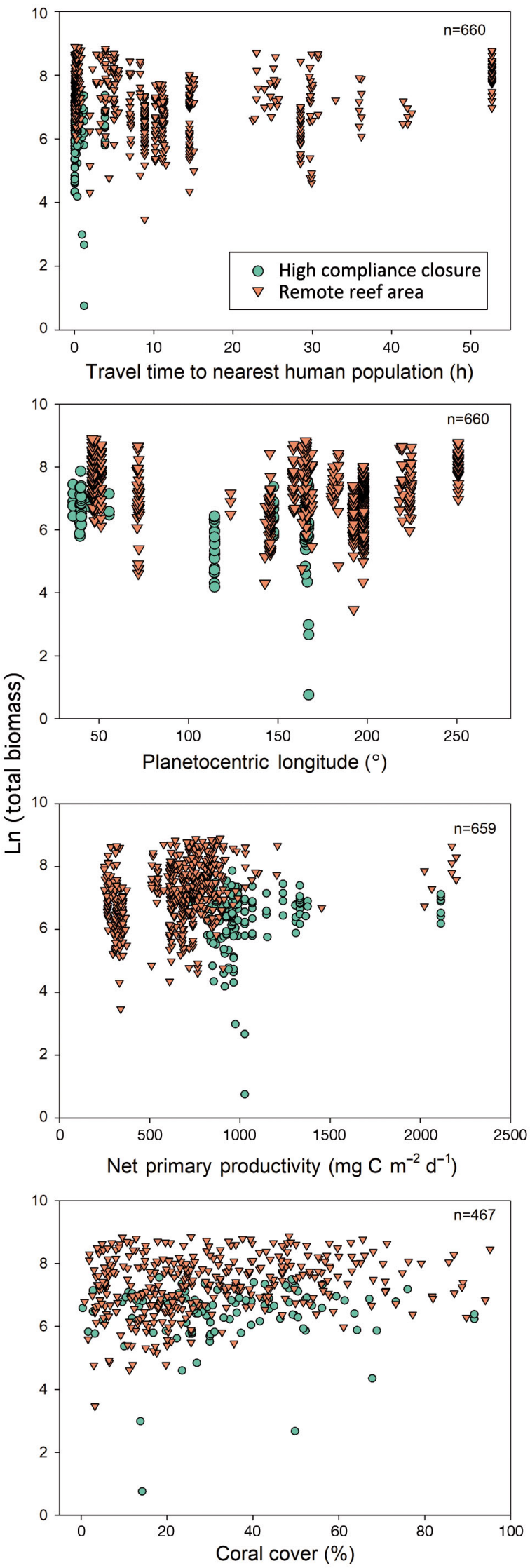

Fig. 3. Bivariate plots showing relationships and levels of significance between fish biomass and the environmental variables of travel time to nearest human population, planetocentric longitude, net primary productivity, and coral cover

\section{DISCUSSION}

This study indicates that high biomass values are geographically widespread but differ considerably between high-compliance fisheries closures and remote reefs. Consequently, closures are not a baseline but may, nevertheless, act as benchmarks for biomass in fished seascapes. Variance in biomass is largely due to differences between sites within ecoregions rather than geography. One exception is that subtropical remote reefs had lower biomass than tropical reefs and weaker geographic gradients in production. Travel time was negatively associated with biomass in closures and therefore not the factor most responsible for differentiating closures and remote reefs. We suggest that the very large distance from cites and ports and isolated aspects of remote seascapes was the cause of the closure-remote reef biomass differences. Additionally, closures responded differently than remote reefs for many of the regression analyses with environmental variables. Conse-

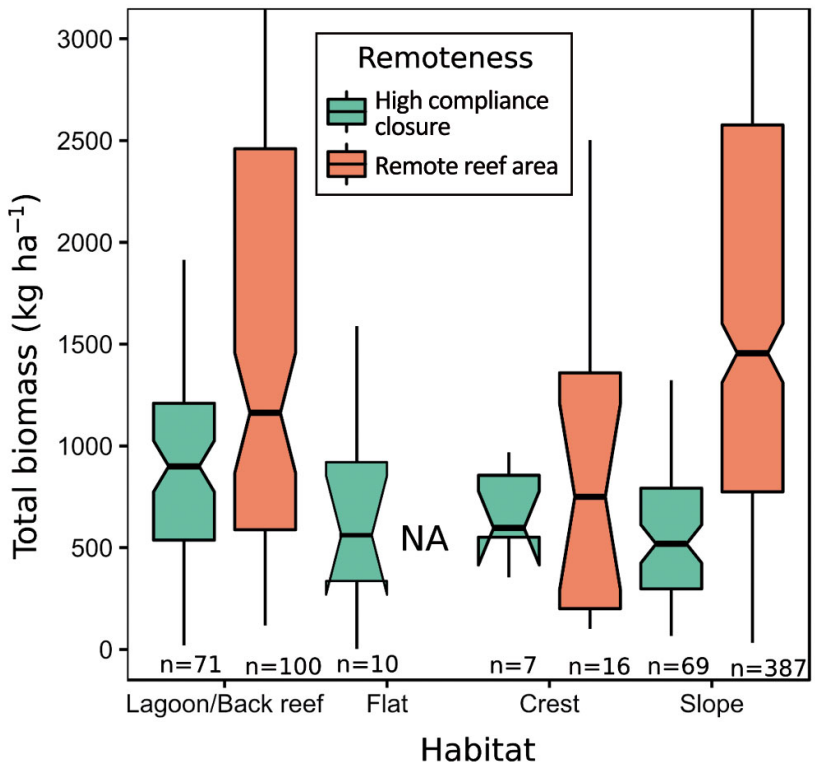

Fig. 4. Butterfly plots of the distribution of fish biomass in high-compliance fisheries closures and remote reef sites across 4 habitat categories. The box shows the interquartile range (IQR), the line shows the median, the notch shows the confidence interval around the median and the whiskers add 1.5 times the IQR to the 75 th percentile and subtracts 1.5 times the IQR from the 25th percentile. NA: not available 
Table 5. Models predicting biomass following forward stepwise regressions for environmental variables and ordinary least squares for geographic variables in high-compliance fisheries closures and remote reef areas

\begin{tabular}{|c|c|c|}
\hline Category & Model & $\mathrm{R}^{2}$ \\
\hline \multicolumn{3}{|c|}{ Environmental fits including categorical variables } \\
\hline $\begin{array}{l}\text { High- compliance } \\
\text { closures }\end{array}$ & $\begin{array}{l}\text { Ln biomass }=7.8+0.4 \times \operatorname{depth}(>10 \mathrm{~m}-4-10 \mathrm{~m})-0.2 \times \text { depth }(4-10 \mathrm{~m}, 0-4 \mathrm{~m})-0.006 \times \\
\text { planetocentric longitude }-0.0009 \times \text { net primary productivity }-0.00002 \times(\text { planetocentric } \\
\text { longitude }-105.634) \times(\text { net primary productivity }-1056.35)\end{array}$ & 0.12 \\
\hline Remote reef areas & $\begin{array}{l}\text { Ln biomass }=5.5-0.1 \times \operatorname{depth}(>10 \mathrm{~m}-4-10 \mathrm{~m})+0.6 \times \text { depth }(4-10 \mathrm{~m}, 0-4 \mathrm{~m})+0.002 \times \\
\text { planetocentric longitude }+0.001 \times \text { net primary productivity }+0.00001 \times(\text { planetocentric } \\
\text { longitude }-139.1) \times(\text { net primary productivity }-668.7)+0.01 \times \text { coral cover }-0.0002 \times \\
\text { travel time to nearest human population }\end{array}$ & 0.26 \\
\hline \multicolumn{3}{|c|}{ Environmental fits excluding categorical variables } \\
\hline $\begin{array}{l}\text { High- compliance } \\
\text { closures }\end{array}$ & Ln biomass $=1.2+0.1 \times$ photosynthetically active radiation $-0.04 \times$ wave energy & 0.15 \\
\hline Remote reef areas & $\begin{array}{l}\text { Ln biomass }=6.0+0.0008 \times \text { planetocentric longitude }-0.0004 \times \text { travel time to the nearest } \\
\text { human population }+0.0003 \times \text { travel time to nearest market }+2.0 \times \text { gravity to nearest market }+ \\
0.006 \times \text { coral cover }+0.001 \times \text { net primary productivity }+0.0009 \times \text { population counts }+ \\
0.00001 \times(\text { planetocentric longitude }-139.1) \times(\text { net primary productivity }-668.7)+0.000003 \times \\
(\text { planetocentric longitude }-139.1) \times(\text { travel time to nearest human population }-1657.0)\end{array}$ & 0.30 \\
\hline \multicolumn{3}{|l|}{ Geographic fits } \\
\hline $\begin{array}{l}\text { High-compliance } \\
\text { closures }\end{array}$ & $\begin{array}{l}\text { Ln biomass }=6.6-0.01 \times \text { planetocentric longitude }+0.07 \times \text { relative latitude }+0.001 \\
(\text { planetocentric longitude }-105.6) \times(\text { relative latitude }-13.0)\end{array}$ & 0.23 \\
\hline Remote reef areas & $\begin{array}{l}\text { Ln biomass }=7.3-0.001 \times \text { planetocentric longitude }+0.001 \times \text { relative latitude }+0.003 \\
(\text { planetocentric longitude }-105.6) \times(\text { relative latitude }-13.0)\end{array}$ & 0.03 \\
\hline
\end{tabular}

quently, closures respond to the environment differently than remote reefs and therefore are a weak analogue for wilderness. The broad seascape/human access context appears to be the most influential factor.
Closures were within nearshore fished seascapes while remote reefs were in large areas of offshore wilderness-often small remote islands. For example, in closures, biomass was stable with closure time and area, suggesting an equilibrium in these values

Table 6. Forward stepwise regression presenting Bayesian information criterion (BIC) results for environmental and habitat influences in the tropics on $\log _{\mathrm{e}}$ total biomass. VIF: variance inflation factor

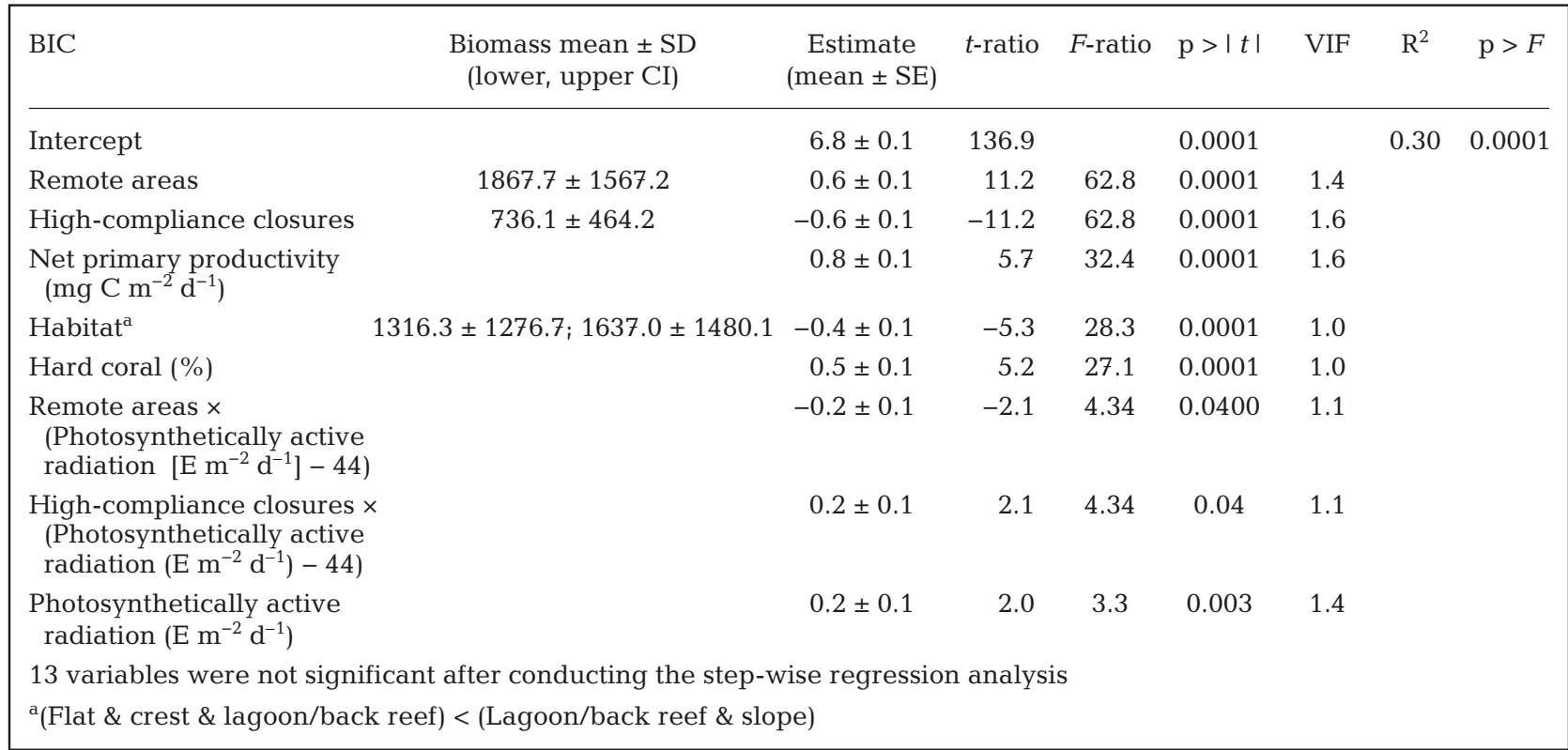




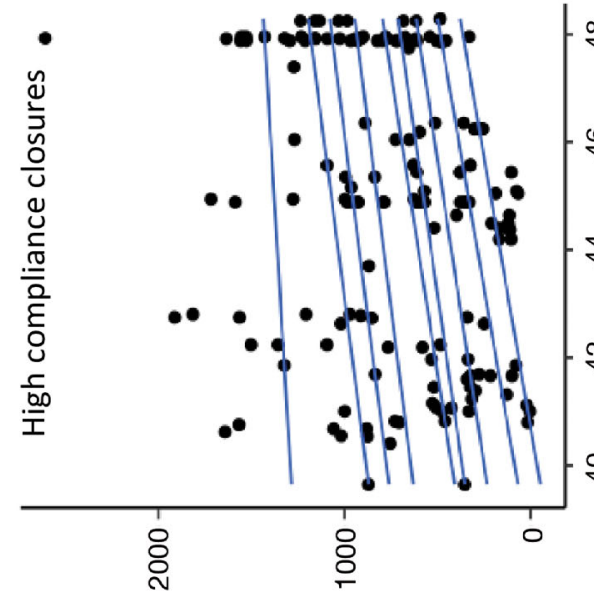

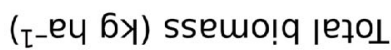

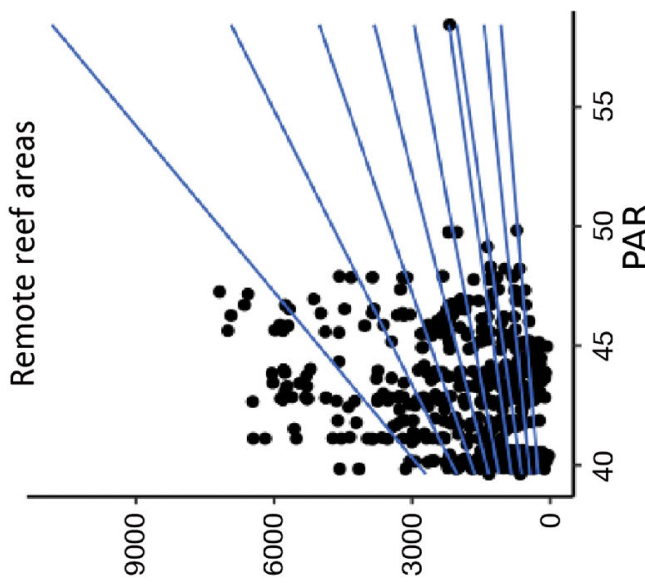

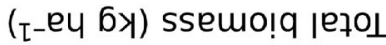

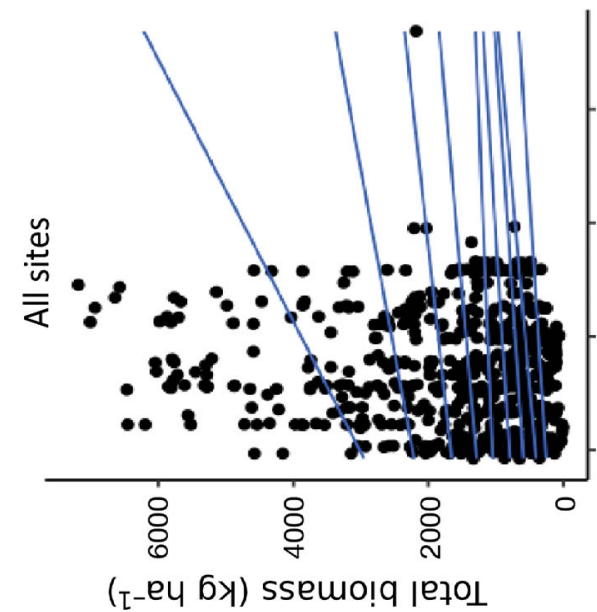

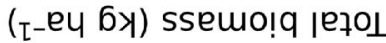

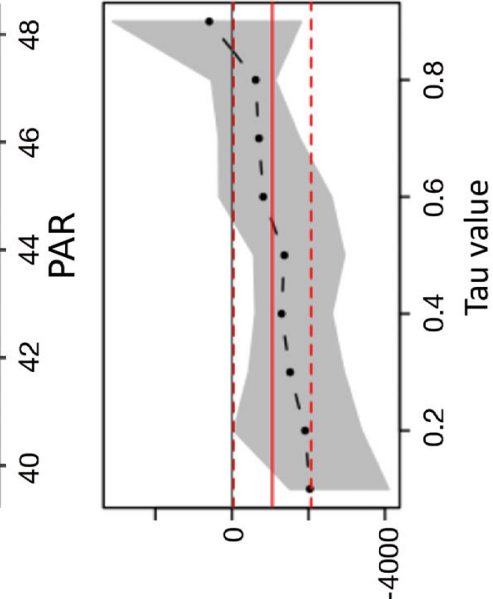

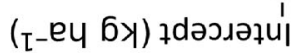

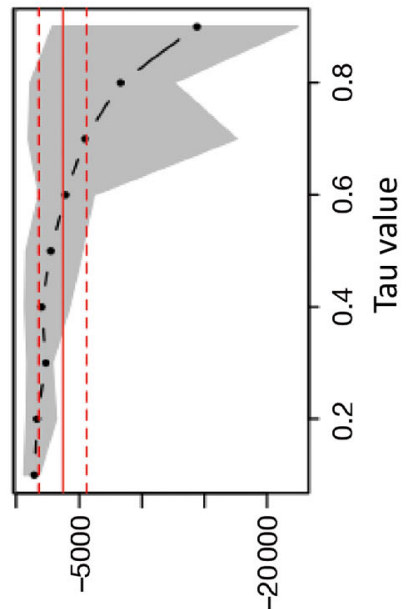

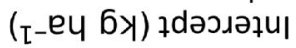

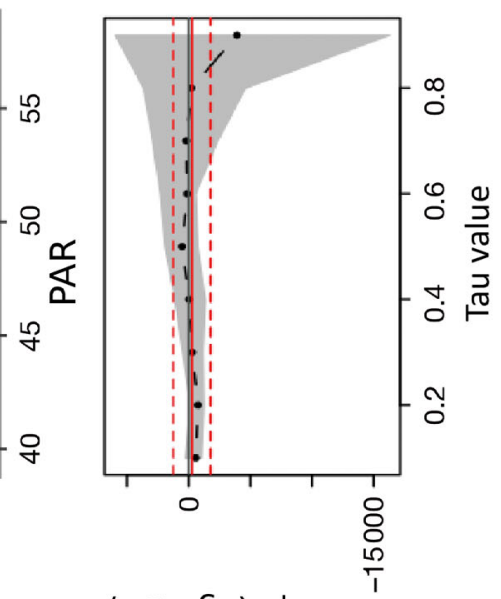

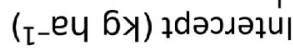

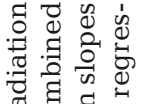

군

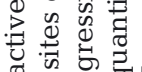

궁

점

of o 우

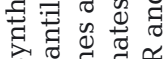

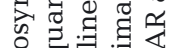

융

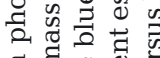

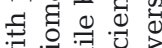

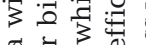

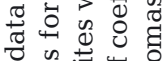

讨

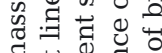

द्व

d 웡

ॠ

पू

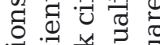

证

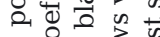

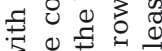

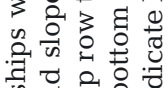

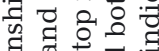

월 च्व

후의

约

जै है है है छ

过

牙译

뎡 $=0$ 원

记

0 u

눙의

0 월 च च

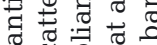

द्र क्षेत् है

용 웡

w

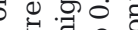

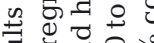

군 중우

dै

क.

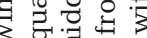

o है है

जी

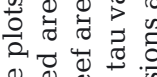

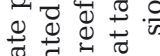

正

在菏

कि

மं $\dot{\vec{x}}=$

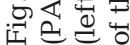




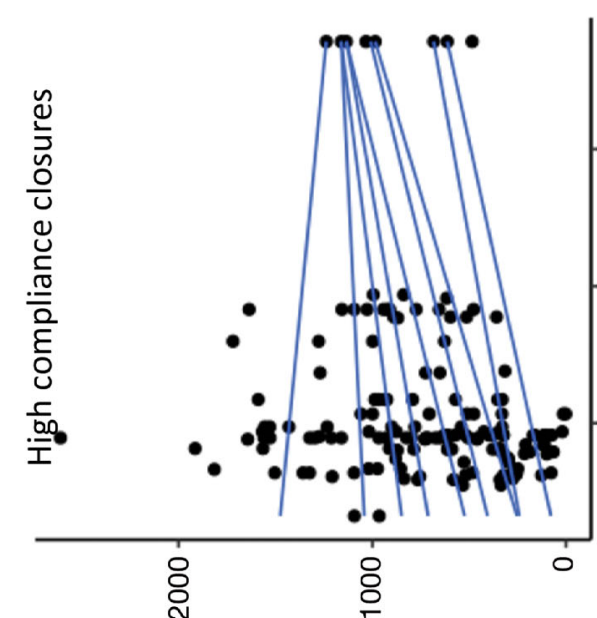

(

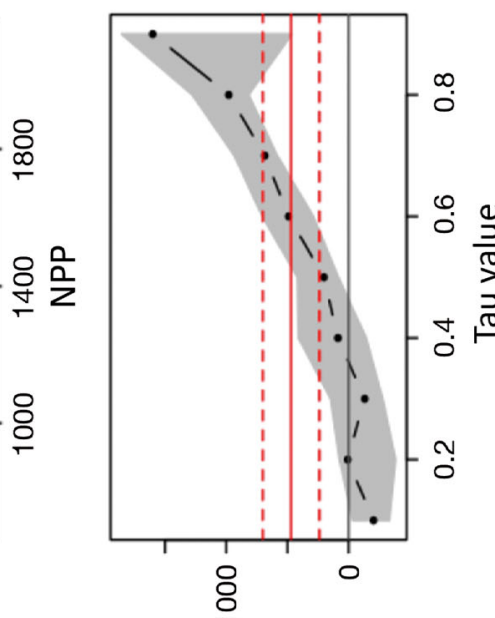

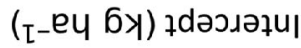

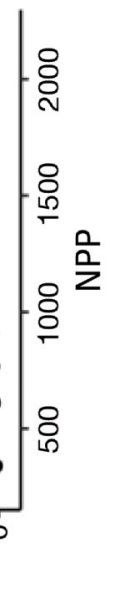

(

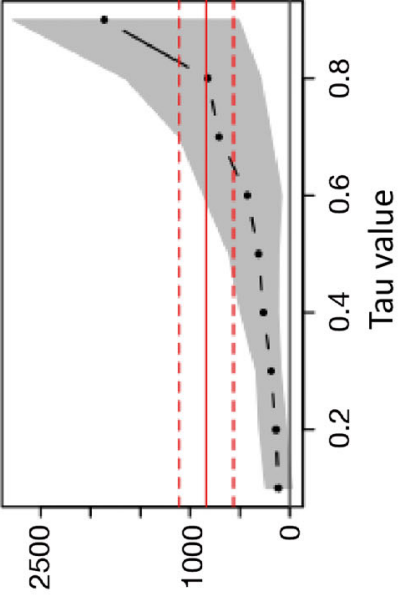

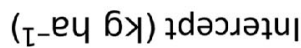

ఏ.

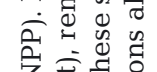

空要要

年

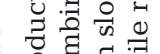

Tे

$\geq$ w

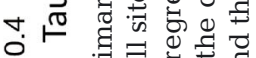

है तै

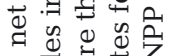

ণ

उ वै.

तु

讨

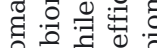
苛 3 过 \&

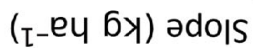
च

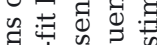

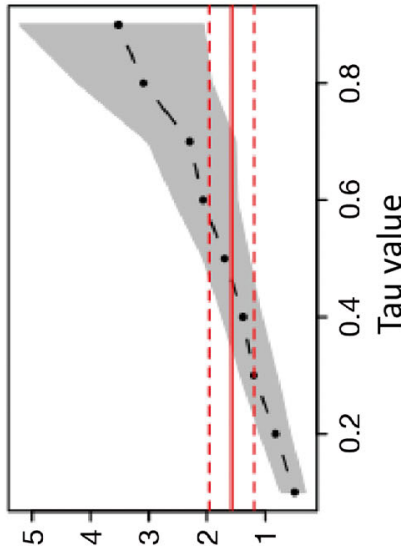

( ¿-ey 6 ㅈ) ədo|s

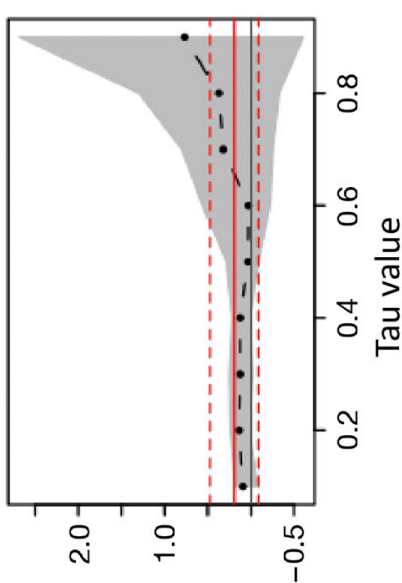

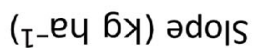

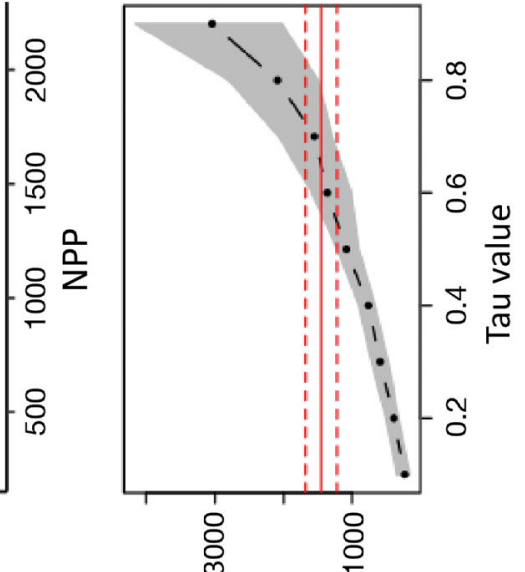

(

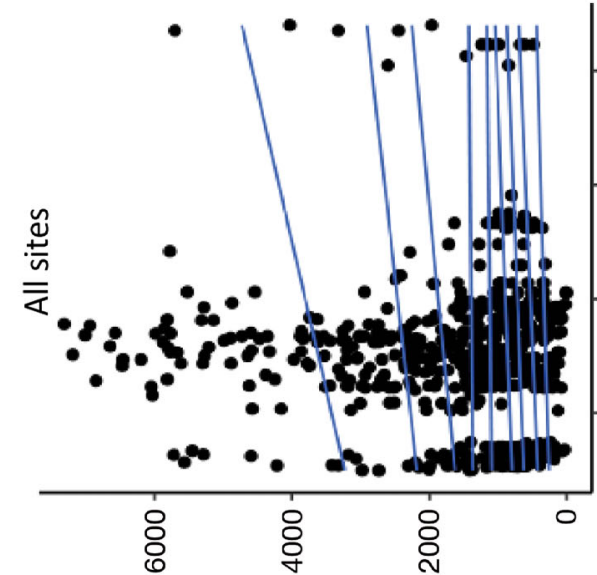

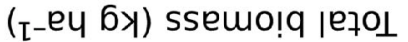




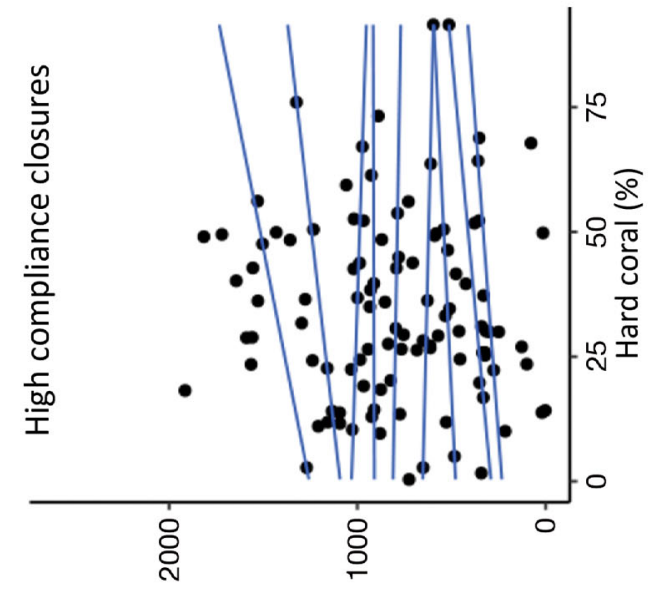

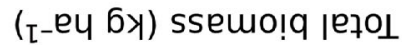

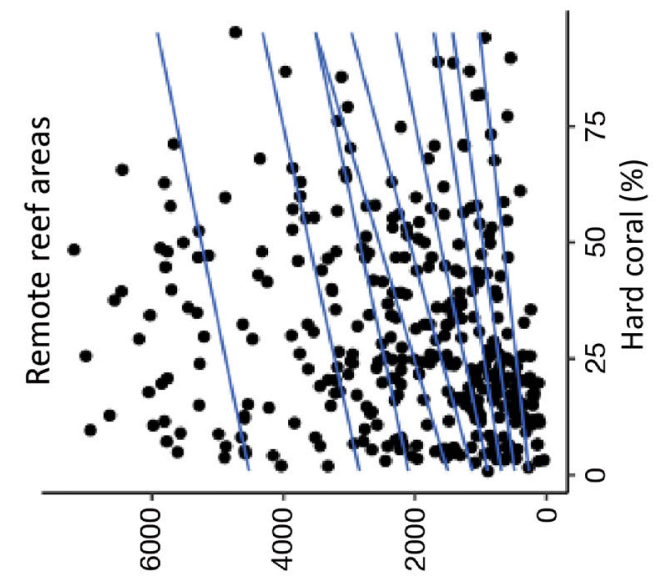

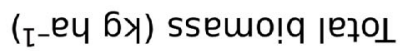

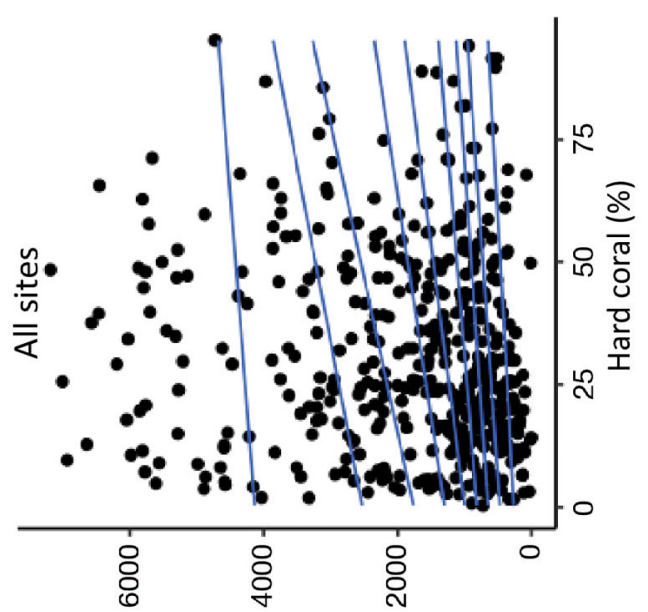

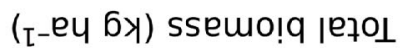

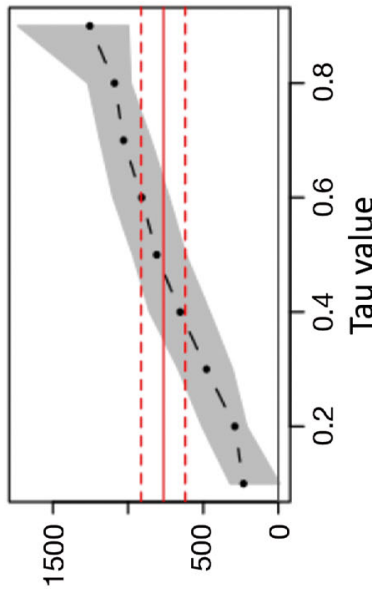

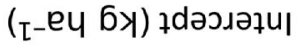

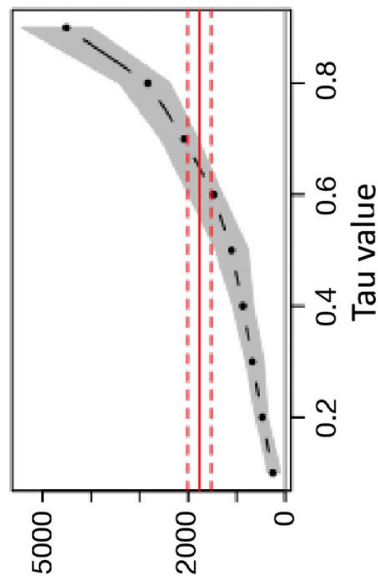

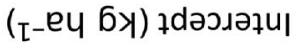

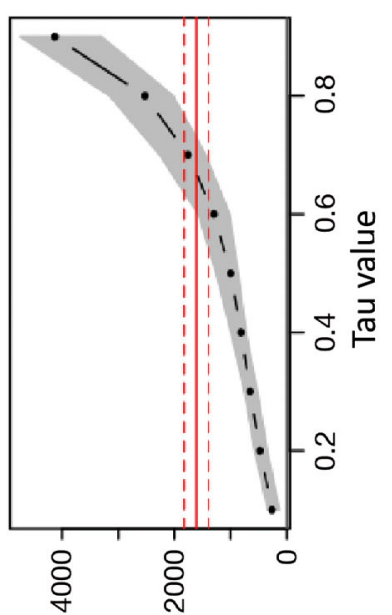

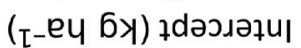

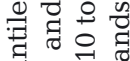

๘

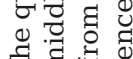

है

ปี

उ]

$\overrightarrow{0}$

ص⿺辶一兀

政

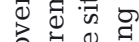

을

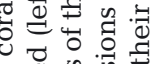

专.

है जी

웡 0

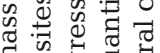

(โ-ey бx) adols

वै छ

․ㅛㅇㅛ

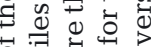

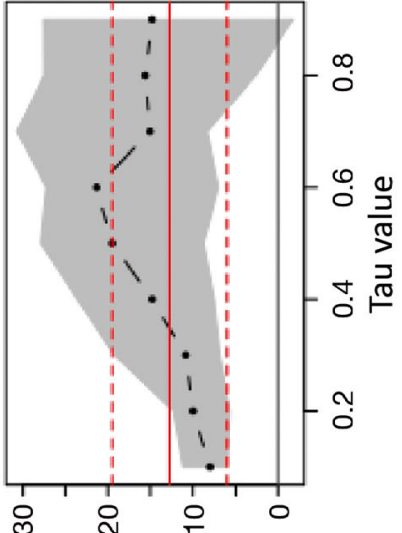

( ¿-ey 6y) ado|s

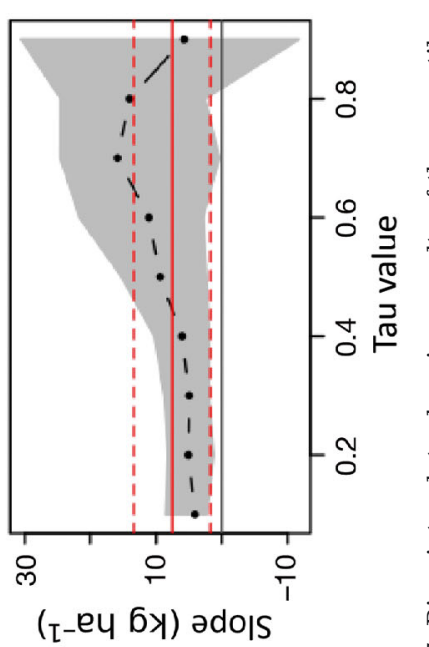

记

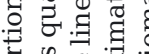

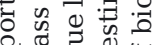

동요

$3: 0$ 궁

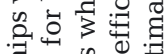

जै

记

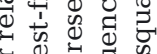

过

की

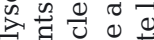

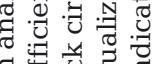

둥

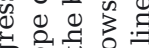

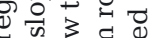

๑ 0 잉

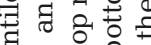

ब요

윰 듀

过

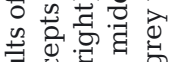

讨

,

역

언 눙

क ज

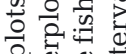

o

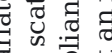

कृ

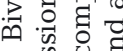

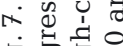

얼 형웡 


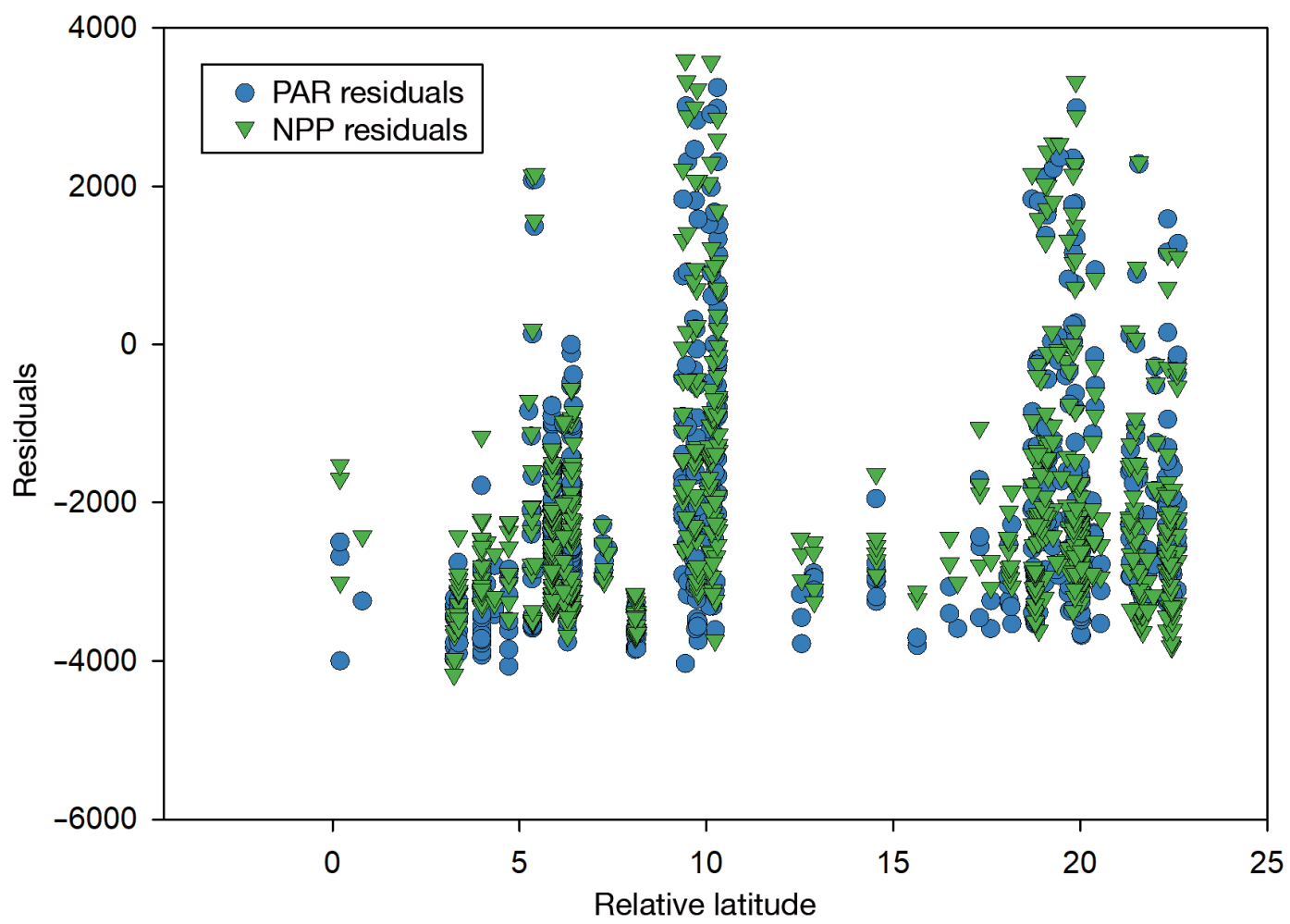

Fig. 8. Bivariate plot showing residuals of the linear regression of biomass versus net primary productivity (NPP) and photosynthetically active radiation (PAR) at the $90^{\text {th }}$ quantile versus relative latitude

at the seascape scale. In contrast, production and habitat were more limiting factors in remote reef sites, as reflected by the variable quantile regression responses for the NPP and coral cover covariates. Therefore, remote reefs had more hard resource limitations than no-take closures. PAR was less limiting in closures but the final biomass was not limited by it because the slope with biomass was constant to declining with increasing biomass quantiles. Moreover, as closures had lower biomasses than remote reef sites, production limitations are unlikely. This produces responses that are scale-dependent when evaluating differences between these reef categorizations.

These complex findings suggest differences in the access, use, and concentration of production in closures and remote reefs. An indication of this complexity and the concentration of biomass is reflected in the high biomass in deeper reef slopes of remote reefs. The implication is that existing closures do not support or contain the full suite of large fish that occupy deeper, and therefore less productive, reef slopes and lagoons that are expected to move and feed broadly. We suggest that closures fail to support populations of many bony fish and sharks that occupy depths or have access to unfished habitats because of the limited size of closures and fishing that occurs outside their boundaries. Consequently, most standard-sized closures will fail to support the high biomasses of remote reefs, and do not represent fish communities present in fully undisturbed wilderness (Graham \& McClanahan 2013, D'agata et al. 2016). Moreover, the selection of coral cover and the changing response in the quantile regression slopes also suggests that biomass in remote reefs is more sensitive to coral than closures. We suggest that where large predators are present, coral refuge may be critical for maintaining high biomass of smaller bodied prey. Previous studies have indicated that sharks can account for a large proportion of the biomass in some remote reefs (Friedlander \& DeMartini 2002, Sandin et al. 2008, Graham \& McClanahan 2013), but here we observed large differences even for bony fishes.

\subsection{Environmental sources of variation}

We uncovered a number of statistically significant influential variables that were reduced by the stepwise regression procedure. This suggests some sensitivity to the variables included in the models as well 
Table 7. Forward stepwise regression results presenting Bayesian information criterion (BIC) criteria for log $\operatorname{lotal}_{\mathrm{e}}$ biomass evaluating the influences of geographic variables in the tropics for (a) raw data and (b) residuals from the environmental and habitat variables

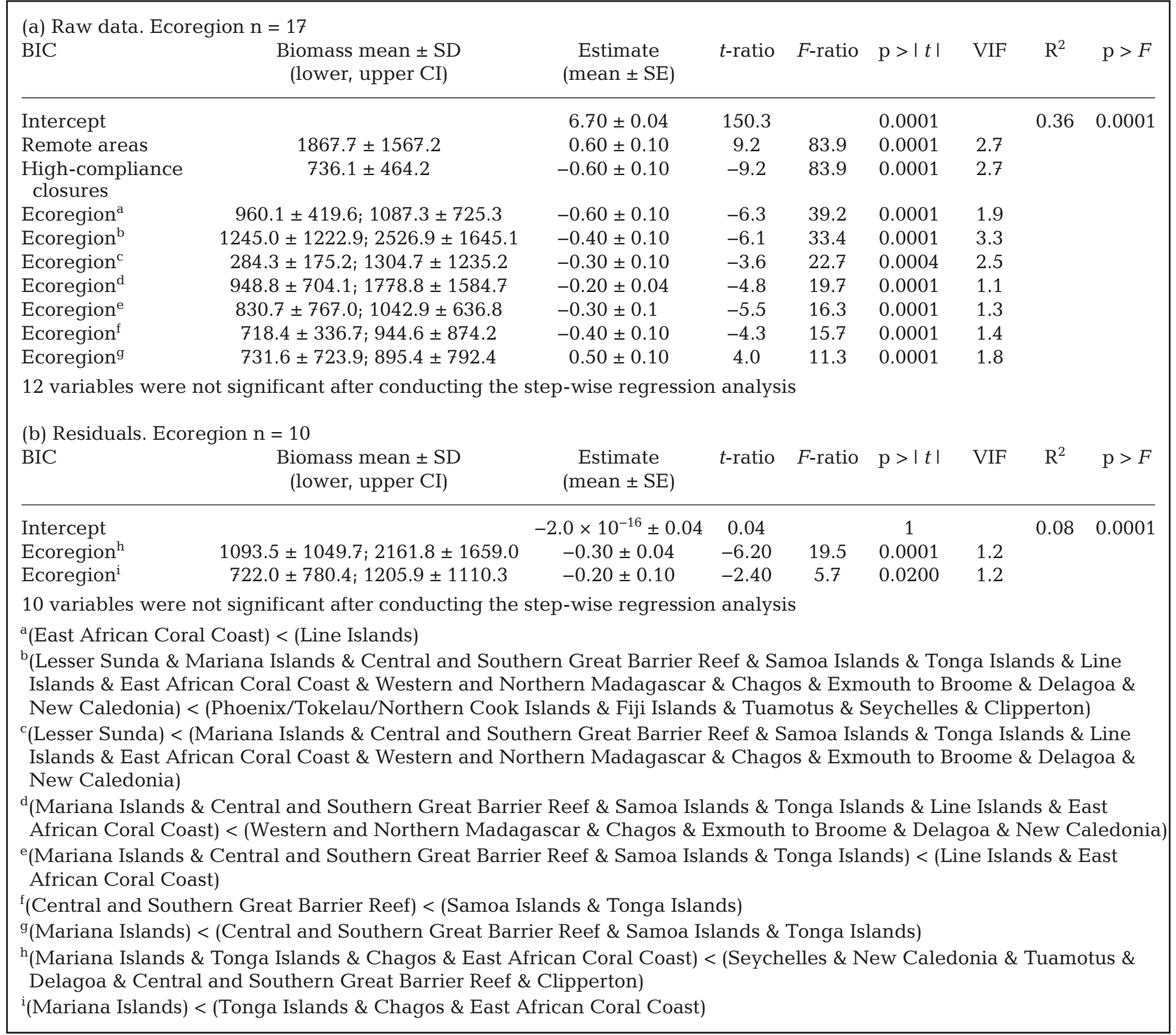

as possible covariation in variables. Most single variables explained a small percentage of the variation that could be eliminated when combined with other variables. The best multiple variable models explained $\sim 30 \%$ of the total variation and often contained significant interaction terms. Removing the environmental sources of variance, particularly the habitat effect, eliminated some of the differences between geographic locations. Consequently, many of the differences in geography were attributable to habitat and environmental factors. Geography was a moderately good predictor of biomass when evaluating closures alone. However, for all residuals only $8 \%$ of the biomass was explained by geographic variables in the 2 statistically significant ecoregions. Directly comparing final mean raw versus residual biomass in the tropics was not possible given differences in the data sources and sample sizes, but raw $\left(1599\right.$ [856, 1038] kg ha $\left.{ }^{-1}, \mathrm{n}=660\right)$ and residual biomass $\left(1843[1699,1987] \mathrm{kg} \mathrm{ha}^{-1}, \mathrm{n}=466\right)$ differences were not large (Tables $2 \& 8$ ).

Biomass variance was further reduced when only the best-sampled regions were evaluated. Two similar final biomass groups emerged when the environmental influences of these better sampled groups were removed. This resulted in a final biomass of $1843 \mathrm{~kg} \mathrm{ha}^{-1}$ with a LCI and UCI of 1699 and $1987 \mathrm{~kg}$ $\mathrm{ha}^{-1}$, respectively. The lack of significance between 
Table 8. Multiple comparison tests of ecoregions in the tropics using the Tukey's honest significant difference on the log transformed total biomass for raw biomass and residuals from environment. Ecoregions connected by the same letter are not significantly different following multiple comparisons. Letters A and B indicate ecoregion clusters based on multiple comparison tests. Blanks indicate that the ecoregion is significantly different from other ecoregions in that cluster. ME: margin of error (based on the standard deviation of the whole data set); SD: standard deviation; COV: coefficient of variation; CI (L, U): confidence interval (lower, upper)

\begin{tabular}{|c|c|c|c|c|c|}
\hline $\begin{array}{l}\text { (a) Raw biomass data }(\mathrm{n}=17) \\
\text { Ecoregion }\end{array}$ & $\mathrm{n}$ & $\mathrm{ME}$ & Mean $\pm \mathrm{SD}$ & & \\
\hline Clipperton & 25 & 0.36 & $3351.9 \pm 1407.8$ & $\mathrm{~A}$ & B \\
\hline Tuamotus & 42 & 0.28 & $2045.2 \pm 1436.5$ & A & B \\
\hline Tonga Islands & 44 & 0.27 & $981.9 \pm 941.5$ & A & B \\
\hline Central and Southern Great Barrier Reef & 15 & 0.44 & $718.4 \pm 336.7$ & A & \\
\hline Samoa Islands & 10 & 0.52 & $780.4 \pm 478.3$ & A & $\mathrm{B}$ \\
\hline New Caledonia & 147 & 0.14 & $1879.9 \pm 1643.8$ & $\mathrm{~A}$ & \\
\hline Line Islands & 93 & 0.18 & $1087.3 \pm 725.5$ & A & $\mathrm{B}$ \\
\hline Delagoa & 5 & 0.72 & $1097.9 \pm 418.9$ & A & $\mathrm{B}$ \\
\hline Fiji Islands & 12 & 0.48 & $1625.3 \pm 620.1$ & $\mathrm{~A}$ & $\mathrm{~B}$ \\
\hline Western and Northern Madagascar & 4 & 0.85 & $972.6 \pm 105.1$ & $\mathrm{~A}$ & $\mathrm{~B}$ \\
\hline East African Coral Coast & 50 & 0.24 & $960.1 \pm 419.6$ & A & $\mathrm{B}$ \\
\hline Phoenix/Tokelau/Northern Cook Islands & 4 & 0.85 & $1581.5 \pm 679.1$ & $\mathrm{~A}$ & $\mathrm{~B}$ \\
\hline Seychelles & 99 & 0.17 & $2670.4 \pm 1778.4$ & $\mathrm{~A}$ & $\mathrm{~B}$ \\
\hline Exmouth to Broome & 4 & 0.85 & $1062.1 \pm 303.3$ & $\mathrm{~A}$ & B \\
\hline Mariana Islands & 45 & 0.27 & $731.6 \pm 723.9$ & & B \\
\hline Lesser Sunda & 28 & 0.34 & $284.3 \pm 175.2$ & $\mathrm{~A}$ & $\mathrm{~B}$ \\
\hline Chagos & 33 & 0.32 & $1615.9 \pm 1554.2$ & $\mathrm{~A}$ & $\mathrm{~B}$ \\
\hline Mean \pm SD & & & $1598.5 \pm 1467.8$ & $1661.9 \pm 1488.5$ & $1541.9 \pm 1417.6$ \\
\hline $\mathrm{COV}$ & & & 91.8 & 89.57 & 91.94 \\
\hline $95 \%$ CI $(L, U)$ & & & $856.4,1038.4$ & $1544.0,1779.8$ & $1417.1,1666.7$ \\
\hline Median & & & 1108.5 & 1207.0 & 1106.1 \\
\hline $95 \%$ CI $(\mathrm{L}, \mathrm{U})$ & & & $1021.5,1236.6$ & $1066.8,1293.7$ & $995.7,1240.2$ \\
\hline \multicolumn{6}{|c|}{ (b) Residuals from environment and habitat associations ( $\mathrm{-}-10$ ecoregions due to missing variables at sites) } \\
\hline Ecoregion & $\mathrm{n}$ & ME & Mean \pm SD & & \\
\hline Tuamotus & 42 & 0.26 & $2045.2 \pm 1436.5$ & A & B \\
\hline Clipperton & 25 & 0.34 & $3351.9 \pm 1407.8$ & A & $\mathrm{B}$ \\
\hline Tonga Islands & 37 & 0.28 & $1048.1 \pm 1009.2$ & $\mathrm{~A}$ & $\mathrm{~B}$ \\
\hline New Caledonia & 145 & 0.45 & $1847.8 \pm 1602.0$ & A & $\mathrm{B}$ \\
\hline Central and Southern Great Barrier Reef & 15 & 0.43 & $718.4 \pm 336.7$ & A & \\
\hline Mariana Islands & 36 & 0.28 & $772.0 \pm 780.4$ & & $\mathrm{~B}$ \\
\hline Delagoa & 3 & 0.90 & $1207.8 \pm 549.1$ & $\mathrm{~A}$ & $\mathrm{~B}$ \\
\hline Seychelles & 97 & 0.18 & $2627.6 \pm 1732.0$ & A & $\mathrm{B}$ \\
\hline Chagos & 33 & 0.30 & $1615.9 \pm 1554.2$ & $\mathrm{~A}$ & $\mathrm{~B}$ \\
\hline East African Coral Coast & 33 & 0.30 & $972.9 \pm 331.4$ & $\mathrm{~A}$ & $\mathrm{~B}$ \\
\hline Mean \pm SD & & $1843.2 \pm 1579.8$ & $1932.8 \pm 1597.3$ & $1880.6 \pm 1591.2$ & \\
\hline $\mathrm{COV}$ & & & 85.71 & 82.64 & 84.61 \\
\hline $95 \%$ CI (L, U) & & $1699.3,1987.0$ & $1781.4,2084.2$ & $1733.3,2027.8$ & \\
\hline Median & & & 1293.8 & 1385.7 & 1320.0 \\
\hline $95 \%$ CI (L, U) & & $1134.1,1431.6$ & $1260.3,1529.2$ & $1161.2,1482.9$ & \\
\hline
\end{tabular}

the best-sampled ecoregions and high site variance does suggest a possible baseline for Indian and Pacific coral reefs. The practical usefulness of this value will, however, depend on the scale of sampling and acceptable margins of error (Table 9). Given the low variance explained by our variables, $\sim 70$ to $92 \%$ of the variance in the biomass at the site level is likely attributable to other factors such as fish movements, aggregation, and habitat associations that are not that well studied or understood. For example, one study that repeated transect censuses over short periods of time found up to $25 \%$ variation in fish numbers could be attributed to immediate and rapid movements of reef fishes (McClanahan et al. 2007). Further, fish may move over the course of days or seasons (Mallet et al. 2016). Consequently, high variation occurs even within transects in a single location over time and not just among distant sites as 


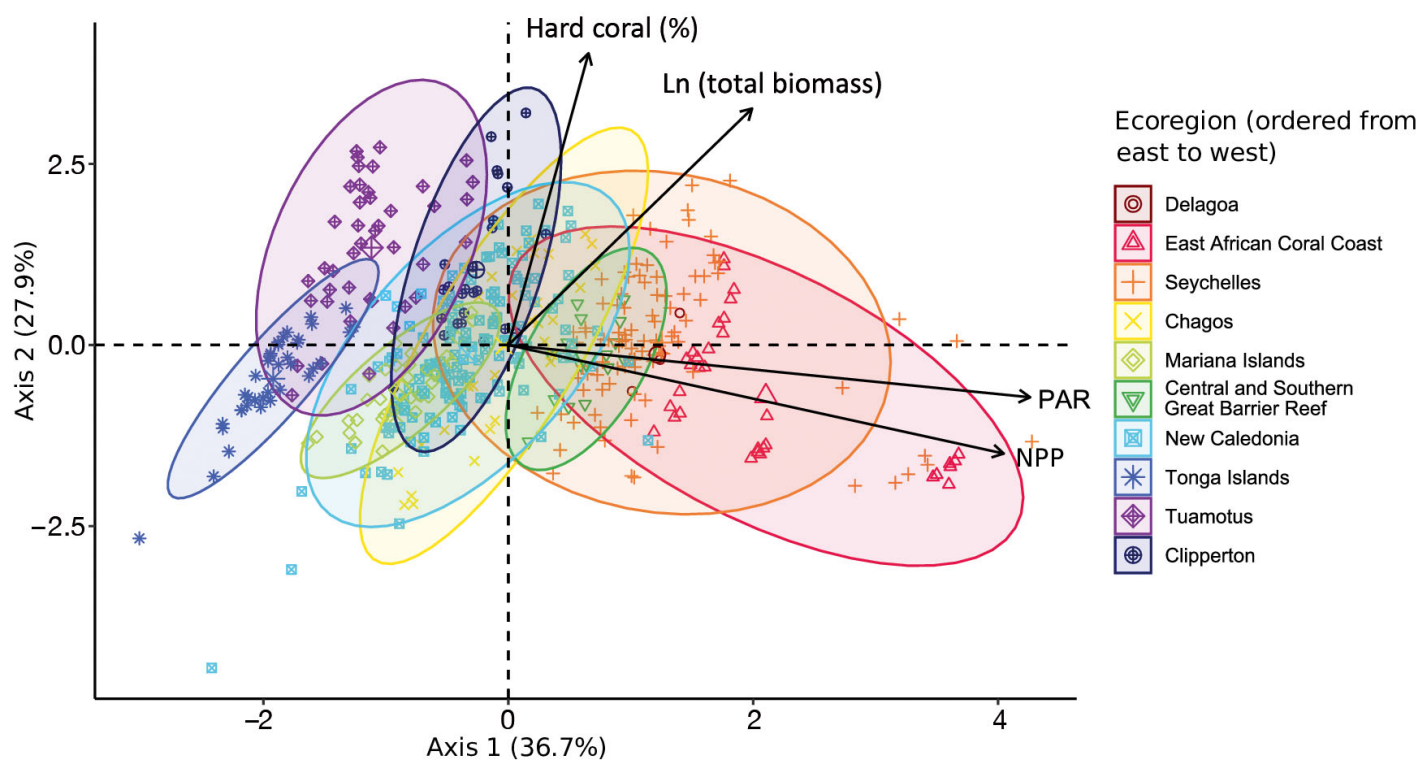

Fig. 9. Multivariate principal component analysis of the total biomass in high-compliance fishery closures and remote reef sites and their associations with the significant environmental and habitat factors in the 10 best sampled ecoregions indicated by the colored ellipses. PAR: photosynthetic active radiation; NPP: net primary productivity

presented here. This further emphasizes the importance of sampling intensity when evaluating fish status with proposed B\&Bs.

A considerable portion of variation in fish biomass may be explained by fish behaviors, such as movements that are associated with feeding, defense, and reproduction (McClanahan et al. 2007). Aggregation explains the right-skewed distributions where biomass is temporarily raised above a baseline determined by harder ecological limits, such as reef production. The right-skew effect can be evaluated by comparing mean and median values. For example, the median (LCI, UCI) biomass was $950(880,1030)$ $\mathrm{kg} \mathrm{ha}^{-1}$ for the best sampled sites. Therefore, the right-skew distribution increased the estimated biomass by $\sim 40 \%$. A large proportion of this biomass is, therefore, attributable to fishes that aggregate on the reef but feed more broadly in surrounding ecosystems and use production from outside the reef (McClanahan 1995). A number of species, of which the most common are aggregating groupers, sweetlips, and snappers, use the reef during daylight but forage more broadly at night (Khan et al. 2017). The high variation between transects and sites is likely to be a result of hits and misses of these aggregating individuals.

Reef degradation was unlikely to have caused biomass differences between closures and remote reef sites. If coral cover is an indicator of disturbance and stress, nearshore reefs had more coral cover than remote reefs. Nearshore reefs had higher chl a concentrations than remote reefs but this appeared to have no effect on decreasing coral cover and increasing biomass. Islands may promote some aggregation of fish supported by local increases in island-generated upwelling or by providing habitats for reproduction (Knip et al. 2010, Gove et al. 2016). Nevertheless, the chl a relationship with biomass was too weak to explain the large observed differences in biomass.

Habitat represented one of the largest influences, which is likely due to the large-bodied fish present in lagoons and slopes of remote reefs. Potential causes are many and conclusive reasons are challenged by the limits of our data. Nevertheless, one explanation is that individuals that use deep water have large home ranges and are poorly protected when closures are small (Kaunda-Arara \& Rose 2004a,b). If so, the closures studied here had attributes that failed to establish a true large-scale production-limited biomass baseline. Given that the protected areas studied here are representative of the global situation in terms of size, age, and possibly enforcement levels (Wood et al. 2008), this limitation is widespread. A third alternative is that remote reefs promote more aggregating species or behaviors than nearshore areas due to connections to deep waters surrounding remote islands. Finally, closures may experience hidden and episodic fishing that reduces biomass more than in remote reefs. Regardless of the causes, it suggests that the presence of humans and their use of the seascape impacts fish biomass and production (McCook et al. 2010, Green et al. 2014, Juhel et al. 
Table 9. Minimum sample sizes (n) of high-compliance fisheries closures and remote reef areas estimated for different margins of error and constant $95 \%$ confidence intervals in different habitat categories and in the tropics vs. subtropics. Sample size (n) $n=\frac{(1.96)^{2} \sigma^{2}}{d^{2}}$ where $\sigma=$ standard deviation (obtained from the global benchmark data set) and $d=$ margin of error. See Table 8 for the sample sizes of the best sampled ecoregions. NA: not applicable

\begin{tabular}{|c|c|c|c|c|c|c|}
\hline & \multirow{2}{*}{$\begin{array}{l}\text { Margin } \\
\text { of error }\end{array}$} & \multicolumn{4}{|c|}{ Sample size (n) } & \\
\hline & & $\begin{array}{c}\text { All } \\
\text { habitats }\end{array}$ & $\begin{array}{l}\text { Lagoon/ } \\
\text { back reef }\end{array}$ & Flat & Crest & Slope \\
\hline \multirow{8}{*}{$\begin{array}{l}\text { High-compliance } \\
\text { closure }\end{array}$} & 0.05 & 611 & 399 & 954 & 170 & 843 \\
\hline & 0.10 & 153 & 100 & 238 & 43 & 211 \\
\hline & 0.15 & 68 & 44 & 106 & 19 & 94 \\
\hline & 0.20 & 38 & 25 & 60 & 11 & 53 \\
\hline & 0.25 & 24 & 16 & 38 & 7 & 34 \\
\hline & 0.30 & 17 & 11 & 26 & 5 & 23 \\
\hline & 0.35 & 12 & 8 & 19 & 3 & 17 \\
\hline & 0.40 & 10 & 6 & 15 & 3 & 13 \\
\hline \multirow[t]{8}{*}{ Remote reef area } & 0.05 & 1082 & 1237 & NA & 2153 & 1017 \\
\hline & 0.10 & 270 & 309 & NA & 538 & 254 \\
\hline & 0.15 & 120 & 137 & NA & 239 & 113 \\
\hline & 0.20 & 68 & 77 & NA & 135 & 64 \\
\hline & 0.25 & 43 & 49 & NA & 86 & 41 \\
\hline & 0.30 & 30 & 34 & NA & 60 & 28 \\
\hline & 0.35 & 22 & 25 & NA & 44 & 21 \\
\hline & 0.40 & 17 & 19 & NA & 34 & 16 \\
\hline
\end{tabular}

(b) Tropics vs. subtropics

Margin Sample size (n)

of error Tropics Subtropics

\begin{tabular}{lccc}
\hline High-compliance & 0.05 & 639 & 307 \\
closure & 0.10 & 160 & 77 \\
& 0.15 & 71 & 34 \\
& 0.20 & 40 & 19 \\
& 0.25 & 26 & 12 \\
& 0.30 & 18 & 9 \\
Remote reef area & 0.35 & 13 & 6 \\
& 0.40 & 10 & 5 \\
& 0.05 & 1078 & 1226 \\
& 0.10 & 270 & 306 \\
& 0.15 & 120 & 136 \\
& 0.20 & 67 & 77 \\
& 0.25 & 43 & 49 \\
& 0.30 & 30 & 34 \\
& 0.35 & 22 & 25 \\
& 0.40 & 17 & 19 \\
\hline
\end{tabular}

2018). Thus, the ratio of closure to fishing area, isolation, human presence, and total closure area may combine to produce our observations.

\subsection{Fisheries benchmarks are different from ecological baselines}

Seascapes with small-sized closure areas is the current state of marine conservation (Wood et al.
2008). Consequently, a benchmark that is lower than the wilderness baseline may be required to evaluate disrupted seascapes typical of tropical countries dependent on fisheries. If so, closures may represent a more realistic maximum biomass or benchmark for fished seascapes. The benchmark is, however, variable across our study region and will need to be calculated for either the geographic location or environmental conditions (Table 5). For example, the reported benchmark biomass found here is nearly one-third lower than reported for the western Indian Ocean (McClanahan 2018). This suggests lower biomass in closures outside of the western Indian Ocean. The African coastline from which most of the data arose did not, however, have any remote reefs and so it is not possible to directly compare $\mathrm{B} \& \mathrm{Bs}$ in this region.

Our findings beg the question of whether benchmark biomass should be restricted to taxa that are fully reliant on the reef production, or, should benchmarks include dayaggregating taxa that are counted during daylight censuses that include individuals feeding more broadly at night? Using median rather than mean values better accounts for this spatial and temporal scale problem and produces a convenient combined B\&Bs tropical and subtropical biomass of $\sim 100$ tons $\mathrm{km}^{-2}$, with $\mathrm{km}$ being the common scale used by fisheries biologists and managers because it is the scale at which fishers capture and return their catches. At this scale, other sand, rubble, and seagrass habitats are fished and many reef-aggregating fish species that feed broadly including nonreef ecosystems are captured (Unsworth et al. 2008). We therefore suggest that managers adjust fisheries benchmark values based on their local geographies and environmental variables (Table 5).

Using the median is convenient for fisheries evaluations but ignores the importance of aggregations associated with patchy production, refuge, or reproduction that typify ecological communities. Ecologi- 
cal status evaluations are mostly concerned with biomass below rather than above a suggested benchmark value. Therefore, caution is needed when lowering a benchmark that would underestimate the ecological roles of these aggregating taxa. Biomass has been used to evaluate ecological change and estimates are likely to be more accurate when using mean biomass (McClanahan et al. 2011, Karr et al. 2015, Selkoe et al. 2015). While these taxa are not fully dependent on the reef, they are part of the reef ecosystem, influence reef processes, and are an indication of the status and health of the reef and surrounding ecosystems (Allgeier et al. 2014).

Benchmarks evaluating fisheries yield potential need to use averages of fish biomass that aggregate on but feed more broadly. Failure to account for this scale problem could overestimate the production potential of fisheries (Thorson et al. 2012). Nevertheless, the intrinsic rate of growth is most important for estimating fisheries production but it must be contextualized by the maximum biomass benchmark (McClanahan 2018). Consequently, using a median biomass will produce more a conservative broad-scale abundance value than means, and therefore be a more realistic estimate of fisheries status.

\subsection{Sampling requirements to estimate bench- marks and baselines}

While the mean values of remote reefs are often consistent, especially when removing some geographic and local environmental influences, the high variation around these means can challenge efforts to evaluate ecological status. Therefore, conclusions about status will be sensitive to sampling intensity. Because variation increases with mean values, the biomass level will determine the accuracy of status estimates and therefore depend on geography, habitat, and levels of fishing (Table 9). It should be recognized that these data and variances are based on sites where transects are pooled in time and space and variance will change somewhat with pooling procedures. Estimations of the status of a reef, management system, ecoregion, or over time will need to consider this variance and accuracy before conclusions can be drawn about either ecological or fisheries status. Fortunately, low biomass fished reefs that are frequently the focus of evaluations will produce the most accurate assessments for the least sampling effort.

\section{CONCLUSIONS}

There are a number of options that need to be considered when establishing biomass B\&Bs for coral reef fishes. Primarily, these include whether the reef is tropical or subtropical, whether protection is afforded by closure or remoteness, and habitat. Remote subtropical reefs are highly variable and therefore evaluations should require more sampling than tropical reefs. Fisheries status may be the least complicated evaluation, and we recommend using median biomass values adjusted for geography.

Previous studies of pristine biomass suggested that biomass B\&Bs in fished landscapes lay within a reasonable range of 1000 to $1200 \mathrm{~kg} \mathrm{ha}^{-1}$ (MacNeil et al. 2015, McClanahan \& Graham 2015). These studies failed to evaluate remote wilderness baselines or habitats. This produced benchmarks that were intermediate between fisheries closures and remote reefs and may be appropriate for fisheries benchmarks and status. Future evaluations will need to consider geography and habitat more carefully and use the values and models presented here (Tables 2 \& 5). Based on our findings, we recommend that 1760 , 1100 , and $1930 \mathrm{~kg} \mathrm{ha}^{-1}$ be used for the ecological status of lagoon/back reef, crest, and slope habitats, respectively, or $1870 \mathrm{~kg} \mathrm{ha}{ }^{-1}$ when sampling and integrating measurements across all habitats.

Some species that have high spatial requirements may not find refuge in even the best managed closures when they exist in fished landscapes. Consequently, they may only persist through speciesspecific management or in high-compliance closures in sparsely fished seascapes. Large and migratory sharks are examples, but there may be other taxa where movements and spatial needs are less obvious and poorly studied. Sharks, for example, respond to no-entry and not just no-take management (Claydon 2004, Robbins et al. 2006, McCook et al. 2010, Juhel et al. 2018). Other large-space requiring bony fish species may also be influential in estimating maximum biomass. Consequently, roaming and largespace requiring species may require other independent metrics, such as stock indicators, to evaluate their status where a benchmark approach is inappropriate. Regardless, studies evaluating ecosystems using fish biomass benchmarks show numerous changes in both the fish communities and ecosystems as biomass declines below target levels (McClanahan et al. 2011, McClanahan \& Graham 2015, Graham et al. 2017). Therefore, evaluating fish biomass is one of the most useful ways to evaluate the ecological and fisheries status of coral reefs. 
Acknowledgements. This overall synthesis work was supported by the Wildlife Conservation Society through a grant from The John D. and Catherine T. MacArthur Foundation. Funding for the individual field studies included support to T.R.M. by United States Agency for International Development, the Western Indian Ocean Marine Science Association Marine Science for Management Program, and the Ecosystem Services for Poverty Alleviation (ESPA) programme of the Department for International Development (DFID), the Economic and Social Research Council (ESRC) and the Natural Environment Research Council (NERC). The study benefited from data collected by the Pristine Reefs project funded by the Total Foundation. The University of Hawaii Joint Institute for Marine and Atmospheric Research and the NOAA (National Oceanic and Atmospheric Administration) Pacific Islands Fisheries Science Center's Coral Reef Ecosystem Program contributed to surveys of the US Pacific Islands, funded by the NOAA Coral Reef Conservation Program. We thank Octavio Aburto-Oropeza, Cakacaka Akuila, Paula Ayotte, Jim Beets, Maria Beger, Pauline Bosserelle, Andrew Johnson, Tasrif Kartawijaya, Eva Maire, Ismael Mascarenas-Osorio, Shinta Pardede, Stuart Sandin, Fakhrizal Setiawan, Gilles Siu, Sukmaraharja Tarigan, and Ivor Williams for either data, logistic, or fieldwork assistance.

\section{LITERATURE CITED}

Allgeier JE, Layman CA, Mumby PJ, Rosemond AD (2014) Consistent nutrient storage and supply mediated by diverse fish communities in coral reef ecosystems. Glob Change Biol 20:2459-2472

Atkinson LJ, Leslie RW, Field JG, Jarre A (2011) Changes in demersal fish assemblages on the west coast of South Africa, 1986-2009. Afr J Mar Sci 33:157-170

Ault JS, Smith SG, Bohnsack JA (2005) Evaluation of average length as an estimator of exploitation status for the Florida coral-reef fish community. ICES J Mar Sci 62: 417-423

Bradley D, Conklin E, Papastamatiou YP, McCauley DJ and others (2017) Resetting predator baselines in coral reef ecosystems. Sci Rep 7:43131

Bruno JF, Valdivia A (2016) Coral reef degradation is not correlated with local human population density. Sci Rep 6:29778

Cinner JE, Huchery C, MacNeil MA, Graham NA and others (2016) Bright spots among the world's coral reefs. Nature 535:416-419

Cinner JE, Maire E, Huchery C, MacNeil MA and others (2018) Gravity of human impacts mediates coral reef conservation gains. Proc Natl Acad Sci USA 115: E6117-E6125

Claydon J (2004) Spawning aggregations of coral reef fishes: characteristics, hypotheses, threats and management. Oceanogr Mar Biol Annu Rev 42:265-302

D'agata S, Mouillot D, Wantiez L, Friedlander AM, Kulbicki M, Vigliola L (2016) Marine reserves lag behind wilderness in the conservation of key functional roles. Nat Commun 7:72000

Darling ES, Graham NAJ, Januchowski-Hartley FA, Nash KL, Pratchett MS, Wilson SK (2017) Relationships between structural complexity, coral traits, and reef fish assemblages. Coral Reefs 36:561-575

* Duffy JE, Lefcheck JS, Stuart-Smith RD, Navarrete SA,
Edgar GJ (2016) Biodiversity enhances reef fish biomass and resistance to climate change. Proc Natl Acad Sci USA 113:6230-6235

Edgar GJ, Stuart-Smith RD, Willis TJ, Kininmonth S and others (2014) Global conservation outcomes depend on marine protected areas with five key features. Nature 506:216-220

Falter JL, Lowe RJ, Zhang Z, McCulloch M (2013) Physical and biological controls on the carbonate chemistry of coral reef waters: effects of metabolism, wave forcing, sea level, and geomorphology. PLOS ONE 8:e53303

* Friedlander AM, DeMartini EE (2002) Contrasts in density, size, and biomass of reef fishes between the northwestern and the main Hawaiian Islands: the effects of fishing down apex predators. Mar Ecol Prog Ser 230:253-264

Gill DA, Mascia MB, Ahmadia GN, Glew L and others (2017) Capacity shortfalls hinder the performance of marine protected areas globally. Nature 543:665-669

* Gove JM, McManus MA, Neuheimer AB, Polovina JJ and others (2016) Near-island biological hotspots in barren ocean basins. Nat Commun 7:10581

* Graham NAJ, McClanahan TR (2013) The last call for marine wilderness? Bioscience 63:397-402

Gaham NAJ, Nash KL (2013) The importance of structural complexity in coral reef ecosystems. Coral Reefs 32: 315-326

* Graham NAJ, McClanahan TR, MacNeil MA, Wilson SK, Cinner JE, Huchery C, Holmes TH (2017) Human disruption of coral reef trophic structure. Curr Biol 27:231-236

* Green AL, Fernandes GL, Alman G, Abesamis R and others (2014) Designing marine reserves for fisheries management, biodiversity conservation, and climate change adaptation. Coast Manage 42:143-159

* Halpern BS, Longo C, Hardy D, McLeod KL and others (2012) An index to assess the health and benefits of the global ocean. Nature 488:615-620

*Heenan A, Hoey AS, Williams GJ, Williams ID (2016) Natural bounds on herbivorous coral reef fishes. Proc Biol Sci 283:20161716

* Hughes TP, Kerry JT, Álvarez-Noriega M, Álvarez-Romero JG and others (2017) Global warming and recurrent mass bleaching of corals. Nature 543:373-377

Juhel JB, Vigliola L, Mouillot D, Kulbicki M, Letessier TB, Meeuwig JJ, Wantiez L (2018) Reef accessibility impairs the protection of sharks. J Appl Ecol 55:673-683

Karr KA, Fujita R, Halpern BS, Kappel CV and others (2015) Thresholds in Caribbean coral reefs: implications for ecosystem based fishery management. J Appl Ecol 52: 402-412

Kassambara A (2017) Practical guide to principal component methods in R: PCA, M (CA), FAMD, MFA, HCPC, factoextra. STHDA. www.sthda.com

Kaunda-Arara B, Rose GA (2004a) Long-distance movements of coral reef fishes. Coral Reefs 23:410-412

* Kaunda-Arara B, Rose GA (2004b) Out-migration of tagged fishes from marine reef National Parks to fisheries in coastal Kenya. Environ Biol Fishes 70:363-372

K Khan JA, Goatley CHR, Brandl SJ, Tebbett SB, Bellwood DR (2017) Shelter use by large reef fishes: long-term occupancy and the impacts of disturbance. Coral Reefs 36: 1123-1132

Kleypas JA, McManus JW, Meñez LAB (1999) Environmental limits to coral reef development: Where do we draw the line? Am Zool 39:146-159

KKnip DM, Heupel MR, Simpfendorfer CA (2010) Sharks in 
nearshore environments: models, importance, and consequences. Mar Ecol Prog Ser 402:1-11

Koenker R (2018) quantreg: quantile regression. R package version 5.35. https://CRAN.R-project.org/packagequantreg

Kulbicki M, Bozec YM, Labrosse P, Letourneur Y, MauTham G, Wantiez L (2005) Diet composition of carnivorous fishes from coral reef lagoons of New Caledonia. Aquat Living Resour 18:231-250

Lê S, Josse J, Husson F (2008) FactoMineR: an R package for multivariate analysis. J Stat Softw 25:1-8

Levin PS, Kaplan I, Grober-Dunsmore R, Chittaro PM, Oyamada S, Andrews K, Mangel M (2009) A framework for assessing the biodiversity and fishery aspects of marine reserves. J Appl Ecol 46:735-742

MacNeil MA, Graham NAJ, Cinner JE, Wilson SK and others (2015) Recovery potential of the world's coral reef fishes. Nature 520:341-344

Maire E, Cinner J, Velez L, Huchery C and others (2016) How accessible are coral reefs to people? A global assessment based on travel time. Ecol Lett 19:351-360

* Mallet D, Vigliola L, Wantiez L, Pelletier D (2016) Diurnal temporal patterns of the diversity and the abundance of reef fishes in a branching coral patch in New Caledonia. Austral Ecol 41:733-744

Mason RL, Young JC (2002) Multivariate statistical process control with industrial applications, Vol 6. Society for Industrial and Applied Mathematics, Philadelphia, PA

McCauley DJ, Young HS, Dunbar RB, Estes JA, Semmens BX, Micheli F (2012) Assessing the effects of large mobile predators on ecosystem connectivity. Ecol Appl 22:1711-1717

McClanahan TR (1992) Resource utilization, competition and predation: a model and example from coral reef grazers. Ecol Model 61:195-215

McClanahan TR (1995) A coral reef ecosystem-fisheries model: impacts of fishing intensity and catch selection on reef structure and processes. Ecol Model 80:1-19

McClanahan TR (2018) Community biomass and life history benchmarks for coral reef fisheries. Fish Fish 19:471-488

McClanahan TR (2019) Coral reef fish community life history traits as potential global indicators of ecological and fisheries status. Ecol Indicators 96:133-145

* McClanahan TR, Graham NAJ (2015) Marine reserve recovery rates towards a baseline are slower for reef fish community life histories than biomass. Proc Biol Sci 282: 20151938

* McClanahan TR, Kaunda-Arara B (1996) Fishery recovery in a coral-reef marine park and its effect on the adjacent fishery. Conserv Biol 10:1187-1199

McClanahan TR, Graham NAJ, Calnan JM, MacNeil MA (2007) Toward pristine biomass: reef fish recovery in coral reef marine protected areas in Kenya. Ecol Appl 17: 1055-1067

McClanahan TR, Graham NAJ, Wilson SK, Letourneur Y, Fisher R (2009) Effects of fisheries closure size, age, and history of compliance on coral reef fish communities in the Western Indian Ocean. Mar Ecol Prog Ser 396: 99-109

* McClanahan TR, Graham NAJ, MacNeil MA, Muthiga NA, Cinner JE, Bruggemann JH, Wilson SK (2011) Critical thresholds and tangible targets for ecosystem-based management of coral reef fisheries. Proc Natl Acad Sci USA 108:17230-17233

*McCook LJ, Ayling T, Cappo M, Choat JH and others (2010)
Adaptive management of the Great Barrier Reef: a globally significant demonstration of the benefits of networks of marine reserves. Proc Natl Acad Sci USA 107: 18278-18285

Molloy PP, McLean IB, Côté IM (2009) Effects of marine reserve age on fish populations: a global meta analysis. J Appl Ecol 46:743-751

Mora C, Aburto-Oropeza O, Ayala Bocos A, Ayotte PM and others (2011) Global human footprint on the linkage between biodiversity and ecosystem functioning in reef fishes. PLOS Biol 9:e1000606

* Mora C, Danovaro R, Loreau M (2014) Alternative hypotheses to explain why biodiversity-ecosystem functioning relationships are concave-up in some natural ecosystems but concave-down in manipulative experiments. Sci Rep 4:5427

Nadon MO, Ault JS, Williams ID, Smith SG, DiNardo GT (2015) Length-based assessment of coral reef fish populations in the main and northwestern Hawaiian Islands. PLOS ONE 10:e0133960

Odum HT (1988) Self-organization, transformity, and information. Science 242:1132-1139

R Development Core Team (2018) R: a language and environment for statistical computing. R Foundation for Statistical Computing, Vienna

Rice JC, Rochet MJ (2005) A framework for selecting a suite of indicators for fisheries management. ICES J Mar Sci 62:516-527

Robbins WD, Hisano M, Connolly SR, Choat JH (2006) Ongoing collapse of coral-reef shark populations. Curr Biol 16:2314-2319

Sall J, Lehmaan A, Creighton L (2001) JMP start statistics: a guide to statistics and data analysis. Duxbury Press, Pacific Grove, CA

* Samoilys MA, Carlos G (2000) Determining methods of underwater visual census for estimating the abundance of coral reef fishes. Environ Biol Fishes 57:289-304

Sandin SA, Smith JE, DeMartini EE, Dinsdale EA and others (2008) Baselines and degradation of coral reefs in the Northern Line Islands. PLOS ONE 3:e1548

Selkoe KA, Blenckner T, Caldwell MR, Crowder LB and others (2015) Principles for managing marine ecosystems prone to tipping points. Ecosyst Health Sustain 1:1-18

* Spalding MD, Fox HE, Allen GR, Davidson N and others (2007) Marine ecoregions of the world: a bioregionalization of coastal and shelf areas. Bioscience 57:573-583

* Stevenson C, Katz LS, Micheli F, Block B and others (2007) High apex predator biomass on remote Pacific islands. Coral Reefs 26:47-51

*Thorson JT, Cope JM, Branch TA, Jensen OP (2012) Spawning biomass reference points for exploited marine fishes, incorporating taxonomic and body size information. Can J Fish Aquat Sci 69:1556-1568

* Unsworth RKF, De León PS, Garrard SL, Jompa J, Smith DJ, Bell JJ (2008) High connectivity of Indo-Pacific seagrass fish assemblages with mangrove and coral reef habitats. Mar Ecol Prog Ser 353:213-224

* Valdivia A, Cox CE, Bruno JF (2017) Predatory fish depletion and recovery potential on Caribbean reefs. Sci Adv 3:e1601303

*Webster PJ, Holland GJ, Curry JA, Chang HR (2005) Changes in tropical cyclone number, duration, and intensity in a warming environment. Science 309: 1844-1846

Williams ID, Baum JK, Heenan A, Hanson KM, Nadon MO, 
Brainard RE (2015) Human, oceanographic and habitat drivers of central and western Pacific coral reef fish assemblages. PLOS ONE 10:e0120516

Wilson SK, Fisher R, Pratchett MS, Graham NAJ and others (2008) Exploitation and habitat degradation as agents of change within coral reef fish communities. Glob Change Biol 14:2796-2809

Wood L, Fish L, Laughren J, Pauly D (2008) Assessing

Editorial responsibility: Konstantinos Stergiou, Thessaloniki, Greece progress towards global marine protection targets: shortfalls in information and action. Oryx 42:340-351

* Worm B, Hilborn B, Baum JK, Branch TA and others (2009) Rebuilding global fisheries. Science 325:578-585

*Yeager LA, Marchand P, Gill DA, Baum JK, McPherson JM (2017) Marine socio environmental covariates: queryable global layers of environmental and anthropogenic variables for marine ecosystem studies. Ecology 98:1976

Submitted: January 15, 2018; Accepted: January 17, 2019

Proofs received from author(s): February 24, 2019 